\title{
'THIS MAY NOT BE REPRESENTED IN THE CURRICULUM DOCUMENTS', AN ANALYSIS OF EARLY CHILDHOOD EDUCATION CURRICULUM FROM ONTARIO COLLEGE PROGRAMS
}

$$
\text { by }
$$

Daniel Gosson, B.A. Early Childhood Studies, Ryerson University, 2013

\author{
A Major Research Paper \\ Presented to Ryerson University
}

in partial fulfillment of the requirements for the degree of

\author{
Master of Arts \\ In the Program of \\ Early Childhood Studies \\ Toronto, Ontario, Canada, 2014
}

(C) Daniel Gosson 2014 


\section{Author's declaration}

I hereby declare that I am the sole author of this MRP.

This is a true copy of the MRP, including any required final revisions. I authorize Ryerson University to lend this MRP to other institutions or individuals for the purpose of scholarly research

I further authorize Ryerson University to reproduce this MRP by photocopying or by other means, in total or in part, at the request of other institutions or individuals for the purpose of scholarly research. I understand that my MRP may be made electronically available to the public 


\title{
'THIS MAY NOT BE REPRESENTED IN THE CURRICULUM DOCUMENTS', AN ANALYSIS OF EARLY CHILDHOOD EDUCATION CURRICULUM FROM ONTARIO COLLEGE PROGRAMS
}

(C) Daniel Gosson, 2014

\author{
Master of Arts \\ Early Childhood Studies \\ Ryerson University
}

\begin{abstract}
This study examines the way in which Early Childhood Educators trained in Ontario college programs are prepared to work with queer populations upon entering the field. This study used post-structuralist, queer feminist, and critical disability theoretical frameworks while analysing the data. A content analysis, informed by critical discourse analysis, was used to assess program documents. Course descriptions from ECE program websites were collected, as well as a total of 33 course outlines from 11 different Ontario college ECE programs, and 9 textbooks identified through the course outlines. Queer content was found to be absent from all but 5 course outlines and 4 textbooks. The need to have queer issues included formally in Ontario ECE curriculum, the othering of queer populations, and the erasure of queer identities are discussed.
\end{abstract}

Key words: queer inclusion, early childhood education, curriculum, critical discourse analysis 


\section{Acknowledgements}

The following acknowledgements name the people who helped me get to where I am today. These are the people without whom I would not have successfully written this paper, and without whom I would not have found a place at Ryerson.

I thank my Mom, who, despite myself, continues to support me. Because of her, I know that I always have a place to go for love and guidance, and that she will always want to know what I am doing. Even if she makes fun of my hair.

I thank the faculty and staff here in the School of Early Childhood Studies at Ryerson. Over the last three years, I grew as an educator, as a student, and as an academic because of you. I thank especially Dr. Rachel Langford for teaching the best undergraduate class I have ever had and her support as my second reader, Dr. Angela Valeo for pointing me towards my program, Dr. Bob Rinkoff for providing my first taste of research, Sophie Bell for being a truly inspirational person, Dr. Donna Koller for providing some of the best classroom interactions I have ever had, and Ellen Whitcroft for telling some of the best stories to have ever been heard in the ECS graduate student lounge.

I thank Dr. Patrizia Albanese for taking me on as a student and seeing this paper through. Her encouragement, attentiveness, critical insight, and practical support were invaluable.

I thank the managers, residence advisors, and fellow academic links at Ryerson Student Housing Services for being my community for three years. Pitman 13 will always feel like home to me. Go Rams Go!

I thank my friends who understood and also supported me in my work by tolerating my disappearance from social life during my research and writing. I include a very special thank you to Stephanie Steinhoff for living with my data strewn around the living room, and allowing me to steal the television to use as my computer monitor after I broke my laptop.

Finally, thank you, Dad. I know you would be proud of what I have accomplished. I will have a slice of cheesecake in your honour. 


\section{Table of Contents}

Author's Declaration $\quad$ ii

Abstract iii

Acknowledgements $\quad$ iv

List of Tables $\quad$ vi

List of Appendices $\quad$ vii

Introduction 1

Statement of issue $\quad 3$

Social location $\quad 3$

Theoretical frameworks $\quad 4$

Post-structuralist $\quad 4$

Queer feminist $\quad 5$

$\begin{array}{ll}\text { Critical disability theory } & 6\end{array}$

$\begin{array}{ll}\text { Literature review } & 9\end{array}$

Children in early childhood settings $\quad 10$

\begin{tabular}{ll} 
Queer parents & 12 \\
\hline Queer educators
\end{tabular}

Queer educators 15

Methodology 23

Sample and recruitment $\quad 23$

\begin{tabular}{ll} 
Data collection & 25 \\
\hline Analytical tools
\end{tabular}

$\begin{array}{ll}\text { Analytical tools } & 27\end{array}$

$\begin{array}{ll}\text { Approach } & 27\end{array}$

Limitations/delimitations $\quad 32$

$\begin{array}{ll}\text { Findings } & 33\end{array}$

Website information $\quad 34$

Analysis of course syllabi $\quad 38$

Analysis of textbooks $\quad 41$

$\begin{array}{ll}\text { Discussion } & 48\end{array}$

Moving from informal to formal curriculum $\quad 49$

Heteronormativity upheld through otherness $\quad 52$

Erasure of queer identity $\quad 57$

$\begin{array}{ll}\text { Revisiting theoretical frameworks } & 60\end{array}$

$\begin{array}{ll}\text { Limitations } & 61\end{array}$

$\begin{array}{ll}\text { Conclusion } & 62\end{array}$

$\begin{array}{ll}\text { Appendices } & 66\end{array}$

$\begin{array}{ll}\text { References } & 75\end{array}$ 


\section{List of appendices}

Appendix A - List of college ECE programs contacted 66

$\begin{array}{ll}\text { Appendix B - Introduction email } & 67\end{array}$

$\begin{array}{ll}\text { Appendix C - Follow up email } & 68\end{array}$

Appendix D - Program offerings spreadsheet $\quad 69$

Appendix E - Number of syllabi received by program $\quad 72$

$\begin{array}{ll}\text { Appendix F - Course syllabi by program and topic } & 73\end{array}$

$\begin{array}{ll}\text { Appendix G - Textbooks collected } & 74\end{array}$ 
'This may not be represented in the curriculum documents', an analysis of early childhood education curriculum from Ontario college programs

\section{Introduction}

The number of same-sex married families has tripled between the 2006 census and 2011 census. According to Statistics Canada (2011) the number of married and common law same sex couples in Canada is now over 64,575. Of these couples, $9.4 \%$ reported in the last census that they were raising children: $80.3 \%$ of these families identified as female same-sex couples, while 19.7\% identified as male same-sex couples (Statistics Canada, 2011). This means that of the 6.29 million couples in Canada, approximately 6070 of them identified as being in a same-sex relationship and raising children (Statistics Canada, 2011). Since the 2005 legalization of samesex marriage in Canada, the number of same-sex couples, particularly those raising children, appears to be on the rise. Does this recognition, enumeration, and legitimization, of same-sex families and their children change the way that we train educators to work with children? For this research paper, I am interested in determining if and how same-sex families with children are represented and discussed in course content of college ECE programs in Ontario to see if these programs train their students to work with LGBTQ+ (lesbian, gay, bisexual, transgender, queer, etc.) parents and their children.

When I began this major research paper (MRP), I had a single question I wanted to answer: how are early childhood education students being trained in Ontario colleges to work with queer populations? While my research cannot directly answer this question, I wondered, of the 6,070 same-sex couples in Canada who identified themselves in the 2011 census as raising children, how many of them interact with early childhood educators who understand how best to 
relate to LGBTQ+ parents and families? Are our early childhood education graduates receiving the education and training needed to properly meet the needs of gay, lesbian, bisexual, transgender, and all other LGBTQ+ identified parents, families, and children?

Throughout this research I was in contact with the various ECE program directors in Ontario colleges, and the directors who emailed me back, more often than not, said that an indepth look at how we train Ontario ECEs to work with LGBTQ+ families and individuals is interesting and important, and something which had not been fully explored in the colleges. One statement by a program director, however, stood out. She too wrote that this was an important project, but she added, "We do discuss LGBTQ parents and the importance of creating an inclusive and open environment as the subject arises in curriculum, but this may not be represented in the curriculum documents you requested". I took this to mean that the topic might be discussed, if it came up in the classroom, or if individual instructors deemed it to be important, but this would be done informally rather than something deemed to be relevant or important by their respective programs. What happens then if an instructor does not believe the experiences of LGBTQ+ parents warrants inclusion into the classroom curriculum? Without formal inclusion into the curriculum, an ECE program may be sending out the message that this family type is not legitimate or worthy of study.

This made me think of how we as a society view disability and inclusion: if an organization puts in a wheelchair ramp, it is suddenly viewed to be inclusive. Regardless of whose body can or cannot access the space, or the classroom, a wheelchair ramp is the sign of an inclusive environment - though, clearly, this is not enough. Obviously, when speaking of disability and accessibility there is much more to be done than simply installing a wheelchair ramp. I believe that this applies to LGBTQ+ individuals and families as well. Informal 
inclusion into the curriculum, taught when instructors take it upon themselves to teach it, felt very much like a wheelchair ramp--an indication that we, too, are inclusive enough to informally talk about LGBTQ+ people, but do not look closely into the course syllabus. You will not find it. Are we merely installing wheelchair ramps, or are we designing a truly inclusive environment for all families?

\section{Statement of issue}

The issue I wish to explore in this paper is: how do we train graduates from Early Childhood Education programs in Ontario colleges to work with LGBTQ+ populations? To do this I conducted a systematic review of information I could collect from individual ECE programs across Ontario, starting broadly with the information available on their websites and eventually burrowing down to individual course syllabi and textbooks used in their courses. What I wanted to uncover through this MRP was two-fold: first, do Ontario College programs formally train ECEs to work with LGBTQ+ populations, and second, how thoroughly do they train Ontario ECEs to work with LGBTQ+ populations?

\section{Social Location}

This issue is doubly important for me. First, I am an ECE who was trained in an Ontario college and I have spent several years working in various childcare and education programs throughout Ottawa and Toronto. After completing my diploma I decided to continue my education at Ryerson University where I completed the Early Childhood Studies undergraduate program, and am currently in the Master of Arts program. Second, it was not until I began taking Master's level courses that I felt that issues which were important to me as a queer educator, and hopefully one day a father, were openly discussed in the classroom. It was the first 
time I felt like I could express myself safely and respectfully on the topic of sexual diversity in early childhood education. When I first began the Master's program I had plans to write my MRP on the topic of blogging, and how the use of a childcare centered blog could create an online community surrounding a center; a community that would encompass educators, parents, and children, alike. Having the ability and support to explore queer issues in the early years, however, I focused most of my work on queer issues throughout the degree.

\section{Theoretical frameworks}

In this MRP I will be using three theoretical frameworks to construct how I view the role of queer inclusion in Ontario college ECE curriculum. All three frameworks build and support each other in helping us understand the importance of quality inclusion of bias-free, pre-service training for early childhood educators.

For the purposes of this paper I will be including one of Michel Foucault's poststructuralist theories: that of constant surveillance and self-regulation. In his work Discipline and Punish (1977), Foucault discusses the prison as mechanism in society to control and condition the body. He wrote that this function is not limited only to prisons, asking, "Is it surprising that prisons resemble factories, schools, barracks, hospitals, which all resemble prisons?" (Foucault, 1977, p. 228). One of the central techniques used by the state for power in these institutions is constant surveillance (Foucault, 1980). Eventually the need for the state to actually watch over and survey individual bodies through institutions such as schools, hospitals, laws, psychiatry, and prison, is diminished as citizens become influenced into self-regulation of their own behavior (Foucault, 1980). The eventual goal of this self-regulation is for the state to control the bio-power of the citizens, to be involved and control the lives and bodies of its 
citizens from birth to death, and to manage everything from disease, health, sexual relations, and marriage (Foucault, 1978).

In terms of this applicability to ECE curriculum, early childhood educators are indirectly and often unknowingly part of how the state aims to control and manage the bio-power of its citizens. Early childhood educators are responsible for educating children, caring of them, making sure they learn skills that are deemed useful to society, and are tasked with watching and guiding parents. Queer societies have always had to regulate themselves, to appear more heterosexual, and an ECE that is trained in an anti-bias curriculum that can support queer parents without judgement or attempting to regulate parents' behaviour (or access to children) would be beneficial for society.

My work and thinking are also framed by two of Judith Butler's queer feminist concepts: gender performance, and heteronormativity. Both concepts are intertwined, making it difficult to explain one without the other. First, Butler believes that all gendered behaviors, those behaviors we commonly associate with stereotypical masculinity or femininity, are performed in accordance with normative heterosexuality (Butler, 1990). For Butler, and for queer feminist theory in general, gender is a social construct which encompasses much more than one's biological sex and the physical sexual organs one is born with. Heteronormativity then is when society assumes that all bodies are heterosexual bodies and the gender expressions of these bodies is based solely on their biological sex (Butler, 1990). By challenging how gender is understood and experienced and by highlighting the artificial, socially-constructed nature of gender, this concept challenges the status quo and supports those marginalized by rigid gender norms, such as those who identify as lesbian, gay, bisexual, transgender, or queer (Ferfolja \& Hopkins, 2013). This means that what society takes as 'natural' gender norms, that men act how 
society deems is masculine and that women act how society deems is feminine, is driven by, “social sanction and taboo," (Butler, 1990, p. 271), and drives individuals by coercive means.

Butler's concepts are highly applicable to the experiences of queer parents, educators, and children, as they break the barrier between private and professional worlds. By drawing attention to their sexual identity, queer parents and queer educators mark themselves as undesirable 'others' within the heteronormative education space (Gray, 2013). Despite great strides taken in terms of rights for LGBTQ people, "We cannot ignore the fact that our society still relies on an assumption that individuals are 'inherently heterosexual' (Chamness, ReeceMiller, Santavicca, 2010, p. 1023). If all bodies are inherently heterosexual then, how are the homosexual others explained and represented? It is believed, when children are presented with a sexual orientation which defies the norm and is thus not 'normal', and that this will have an influence on children, perhaps making them homosexual as well; this imagined (and problematic) influence of a LGBTQ+ teacher or parent to transform heterosexual children into homosexual children has been called 'gay recruitment' (Chamness et al., 2010).

Finally my work draws upon Critical Disability Theory, which comes from the Disability Rights Movement. Attempting to make the same gains made during the civil rights movement by other groups, disability activists sought to have disability recontextualized as an identity, just as 'race' or sexuality has been (Marks, 1997). One of the goals was to move away from academic and medical terms such as 'people with disabilities' to 'disabled people', arguing that, "If disability is accorded the same status as other identities, such as sexuality or 'race', then, just as we would not talk about a 'person with black skin' or a 'person with homosexual desires', we should not talk about a "person with a disability'” (Marks, 1997, 85). 
There are two terms that are crucial to understanding Critical Disability Theory. The first is 'impairment,' which was defined as, "Lacking part of or all of a limb, or having a defective limb, organ or mechanism of the body" (UPIAS, 1975, p. 4); and the second, 'disability', which is defined as, "the disadvantage or restriction of activity caused by a contemporary social organization which takes no or little account of people who have physical impairments and thus excludes them from participation in the mainstream of social activities" (UPIAS, 1975, p. 4). This social exclusion is then, to Disability Rights Activities, oppression based on body.

The second key concept to take from Critical Disability Theory is the difference between the social model of disability, and the medical model of disability. The social model of disability is defined as, "Locating disability not in the impaired or malfunctioning body, but in an excluding and oppressive social environment." (Marks, 1997, p. 88). This is in contrast with the medical model of disability, defined as, "Focusing on individual pathology and attempts to find ways of preventing, curing, or (failing these) caring for disabled people. Given that the focus is on the individual, a central concern is to make an accurate diagnosis for their 'condition"” (Marks, 1997, p. 86). The medical model is the predominant view of disability in society. This bars disabled people from living independently as they must rely on medical professionals to provide a diagnosis for their 'condition' in order to be 'cared' for by the state and medical institutions who act as gatekeepers to distribute benefits and services (Marks, 1997). Critical Disability occupies the space between these two theories, accepting that disability is socially constructed and separate from impairment, while accepting some aid from the medical establishment in terms of tools and support to be able to live independently, rather than being seen as victims and patients with diagnoses (UPIAS, 1975). 
While disability theory may seem to be an odd choice when investigating the experiences of queer people, I believe it is a useful framework to consider the experiences of queer parents, teachers, and children in two respects. First, consider the nature of impairment versus disability; I argue that homosexuality has been treated as an impairment. That is not to say that homosexuals are lacking or infirmed in some way, but rather that they are different from the heterosexual majority and that the myths that connect homosexuality to pedophilia and create, "A public sense of anxiety and confusion," (Ferfolja \& Hopkins, 2013, p. 318) disables queer parents and teachers. The school is designed to be a heterosexual environment, just as society is designed for the 'normal' able bodied person. I argue that a queer person's sexuality then acts as a barrier, imposed by the education system, through lack of recognition and inclusion. This robs queer people of their identity. Just as hospitals and other constructs are designed to cure or treat the disabled, so too do public school administrators and childcare directors, "Pressure queers to pass as non-queer as well as follow tightly dichotomous gender roles," (Lugg, 2013, p. 46), masking their homosexuality so they better pass as heterosexual.

I argue that combined, these three theoretical frameworks help us to better understand and perhaps tackle the barriers to LGBTQ+ parents through a critical look at curriculum and college-level ECE training. Through post-structuralist concepts of observation and power, as well as queer feminist concepts of gender performance and heteronormativity, a common language can be created to discuss what is happening in classrooms across Ontario: both the college classrooms, as well as early years programs. Finally, viewing accessibility to programs and inclusion for LGBTQ parents in the same way that educators discuss disability provides a rich opportunity to re-examine how we view LGBTQ+ inclusion into curriculum for Early Childhood Educators. 


\section{Literature review}

Before looking in-depth at how early childhood educators are trained in Ontario, several items must be established: first, we must have a common language; second, we must have a common understanding of the experiences of the various actors involved in the field of ECE; and finally, we must have a common understanding of how critical discourse analysis can be used to examine queer issues. On the first issue, common language, I will be using the word 'queer' to describe the LGBTT2SIQQA community, which is the acronym used by Ryerson University Equity Services describe the wider community made up lesbian, gay, bisexual, transgender, transsexual, two-spirited, intersexed, queer, questioning, and their allies (Discrimination and Harassment Prevention Services, 2014). I have chosen to use the term 'queer' rather than an acronym, in order to be most inclusive, as there is great variation in the acronym itself (LGB, LGBTA, GBLT, GBLTT, etc.) depending on who is using the acronym and who is considered to be in the community. Further, depending on who is creating the acronym certain letters are excluded. For instance, those who are transitioning, gender-queer, gender-fluid, asexual or demi-sexual, are not present in the Ryerson acronym. So for the purposes of this paper the word 'queer' will be used to describe someone who breaks from the heteronormative expectations of society in some way, encompassing all letters in the acronym without using it. Queer is also used by many advocates and members of the LGBTQ community because it operates in defiance of the heteronormative assumption of gender and sexual binary such as male and female, heterosexual and homosexual (Peters, 2005; Janmohamed, 2010). Queer also denotes a certain fluidity in gender and sexual identity that cannot be fully encompassed by any of the identities contained within the LGBTT2SIQQA acronym. For these reasons, as well as not wanting to 
erase any identity, I have primarily used 'queer' within this paper to encompass all gender identities and sexualities which differ from the perceived heterosexual norm (Peters, 2005).

As for the second issue, the following section contains a literature review looking at the three main actors found in the early learning environment: children, parents, and educators. As this study is focused on an analysis of the inclusion of queer material in the pre-service training of early childhood educators in Ontario colleges, the focus will be on queer and gendernonconforming children, queer parents, and queer educators. By recognizing the presence of, and understanding the history and current position of these three groups within early educational settings, the need for such pre-service training can be established.

\section{Children in early childhood settings}

\section{Lack of sexuality and heteronormativity}

There is a widespread belief within society that children do not have a sexuality, let alone a queer one, and that they are free of any sort of sexual or romantic notions. As a result, children are seen as, "Asexual, naïve and innocent" (Robinson, 2008, p. 116). We, as a society, generally hold that this innocent view of children must be protected, and the best way to do so is to protect them from anything even faintly sexual. The view of children as innocent and without a sexuality is informed primarily by the developmentalist view of childhood, whereby children are in the process of becoming, rather than the state of being (Robinson \& Davies, 2008). Children are thereby placed in a sort of 'pre-sexual' phase, where they should have no knowledge of sexuality, let alone have any sexuality of their own, until later in life. As has been noted, "Sexuality has become representative of adulthood and it is perceived to be a critical boundary differentiating adulthood from childhood" (Robinson, 2012, p. 261). 
Since children are not recognized as having a sexuality or sexual orientation of their own, heterosexualization, which is heterosexual behaviours that are normalized and create the thought that children are naturally heterosexual (Butler, 2004), become unseen and unacknowledged. This can be problematic as children are not allowed to self-identify as anything other than heterosexual, if they must take any identity other than asexuality. This normalization of heterosexuality and forced heterosexual identity creates the abnormalization of other sexual identities (Butler, 2004).

The heteronormative assumption on sexuality is pervasive yet invisible in early childhood settings (Garcia \& Slesaransky-Poe, 2010; Gunn, 2011; Robinson, 2012; Robinson, 2013, Myers \& Raymond, 2010). Despite some change, Christian morals and values, which are, for the most part, our society's morals and values, continue to centre on the heterosexual nuclear family and marital reproduction (Robinson, 2013). At a societal level, the heterosexual nuclear family is privileged above all other family forms, and especially above queer headed households (Gunn, 2011).

Fear and anxiety over non-heterosexual identities

Disruption or non-conformity to the gender binary by children creates fear and anxiety for parents and educators who are often uncomfortable with unfamiliarity or alternate gender expressions (Garcia \& Slesaransky-Poe, 2010). Again, while we claim to be protecting children from sexuality, we are imposing upon them heteronormative expectations. Children are expected to conform to the gender binary and the implicated heterosexuality that emerges from it. Adults, such as educators and parents, encourage children to hold themselves as heterosexual subjects, and through this process heterosexuality is supported as normal (Surtees \& Gunn, 2010). Thus, heterosexuality is, “Accepted as part of children's daily worlds even when sexuality is perceived 
as irrelevant" (Surtees \& Gunn, 2010, p 45). Garcia and Slesaransky-Poe (2010) have named this silencing effect as being pushed into a "gender closet", and is the result of fear and anxiety to the disruption of heteronormativity. The purpose of the "gender closet" is to keep individuals with non-conforming genders hidden (Garcia \& Slesaransky-Poe, 2010). The silencing of alternate sexualities and gender expressions is, "Perhaps the most insidious effect of heteronormativity" (Gunn, 2011, p 42).

Eliminating sexualities other than heterosexuality interferes with children's accurate understanding of sex, gender, and sexualities. Furthermore, guarding this knowledge overlooks children's rights as social agents, not to mention that it masks and negates their experiences if they are growing up in queer families. The inability to access alternative sexualities allows the heternormative discourse to prevail (Gunn, 2011). This increases adults' anxiety over nonconforming gender identities and contributes to discrimination (Garcia \& Slesaransky-Poe, 2010).

\section{Queer Parents}

Gender roles in queer headed families

As the family unit is where the majority of gender roles are reinforced, and society expects that parents will raise their children to have the 'appropriate gender roles', much attention has been paid to how queer headed families raise their children (Lev, 2010). The roles that policy makers assume for parents are highly gendered, with a the masculine provider parent who acts as a force for discipline and a feminine caregiver parents who acts as a nurturer for the children (Berkowitz \& Ryan, 2011). For the most part, the gender roles assumed by family policies assume that gender roles are tied to biology (Murphy, 2010; Berkowitz \& Ryan, 2011). This is particularly important at the Provincial level, which controls quality and access to 
education, healthcare, and family law, as Canada does not currently have a national level family policy (Rose, 2012). Within the Canadian context these policies are extremely evident within healthcare, where matters such as blood donations by gay men, the availability of hormone injections for transgender Canadians, and even the mother-father binary which appears on birth records, are still hotly debated topics (Mule \& Smith, 2014).

Changing nature of the form of queer headed families

The most common method for queer parents to form a family with children has traditionally been becoming partners with someone who already has had at least one child from a previous heterosexual relationship. It was historically more common for queer men and women to have heterosexual identities and marriages before claiming a $\backslash$ queer identity and ending their heterosexual marriage (Moore \& Stambolis-Ruhstorfer, 2013). The greater social and political acceptance of queer people in the last 20 years, however, has begun to increase the number of families created through adoption and through the use of surrogates (Moore \& StambolisRuhstorfer, 2013).

\section{Children of LGBTQ Parents}

Critics of queer parenting argue that the rights and welfare of children are violated when they are born and raised into LGBTQ headed families, as they were not given the chance to be raised in a heterosexual family (Murphy, 2010). Children of queer headed families have reported just as much love and support from their parents as their peers from heterosexual families (Becker \& Todd, 2013). The only major difference found between children raised in queer families and children raised in heterosexual families is that often times children raised in queer headed families, particularly by lesbian mothers, tend to be more aware of social justice issues, 
as well as more aware of their own behavior in regards to historical gender roles (Lev, 2010).

The act of being raised by members of a marginalized population appears to make children more aware of society, power, and oppression

According to Rosenfeld's (2010) study of the school achievement children from queer households fare no different than their peers from heterosexual households when it comes to grades and retention. Differences do occur, however, when the parents in queer families do not have legal recognition of their relationship. Rosenfeld (2006) argues that the lack of legal and institutional support afforded to LGBTQ couples whose relationships are not officially and legally recognized acts as a barrier for student achievement in school. Certain advantages available to heterosexual couples who have their marriages legally recognized, such as employer health insurance and joint tax credits, are not available to queer couples who do not have their marriage legally recognized. This has become far less of a concern in Canada since the introduction of Bill C-38 which granted same-sex couples the right to marry, giving same-sex couples the choice of marriage or remaining common law (Rose, 2012). At the same time, given the slow pace of change in the actual practice of inclusion in various day-to-day matters, such as in education or the general workforce, some queer families continue to choose to remain unaccounted for, for fear of negative repercussions.

\section{Transgender parents}

There is no published evidence that suggests that children raised by transgender parents experience any sort of harm while growing up (Murphy, 2010). There can be an estrangement between transgender parents and their children if the parent transitions later in the child's life, particularly if the act of transition leads to the dissolution of a heterosexual marriage and identity 
(Knopf, 2013). There is, however, no research currently available on this adjustment process and the effect it has on a family unit or how long a period is needed for children to adjust to a parent's new gender identity.

Gaps in knowledge on queer parents

There are several other areas, however, which require further research to fill our current gaps in knowledge. These include: research on children raised within polyamorous families or with multiple same sex co-parents; the experiences of transgender parents in accessing family resources; the experiences of gay fathers and transgender parents and children raised by them as most research is on lesbian mothers; child focused research on children's own experiences being raised by queer parents; the experiences of bisexual parents.

\section{Queer educators}

The following section discusses the literature as it pertains to the experiences of queer educators in the educational system. For the purposes of this literature review, specific attention was made to collect articles which discussed educators in the early years, or at the very least focused on educators of younger children no older than grade 3 in the school system.

While it has been discussed that the educational system itself is heteronormative (Ferfolja \& Hopkins, 2013; Mayo, 2008; Lugg, 2006) in some cases there are human rights laws put in place to protect queer educators from being fired without any due cause (Chamness, ReeceMiller, \& Santavicca, 2010). This was not always the case, however, especially in the United States. Jackson (2006) described a campaign by singer and orange juice spokesperson Anita Bryant in 1977 to have a non-discriminatory ordinance in California overturned because it protected gay and lesbian teachers. This campaign was very successful and saw a purge of all 
known queer educators in California, using the slogan "Save Our Children" (Jackson, 2006, p. 28), for fear that these teachers were sexual predators who were preying on students.

Being 'out of the closet' is a rite of passage that queer people experience that needs to be understood in order to fully appreciate the concern queer teachers have with being open about their sexuality. 'Coming out of the closet', also known simply as 'coming out', is the act of anyone who identifies as queer in making known their sexual orientation or gender identity to others. This act was named and began after the Stonewall riots of 1969 when police in New York City raided a well-known gay establishment, the Stonewall Inn. This was an event that is argued by many to be the birthplace of the gay liberation moment (Nixon \& Givens, 2004). The act of coming out was designed to combat the largely medical model view of homosexuality; the view at the time by hospitals and psychiatrists was that homosexuality was a psychiatric disorder that could be cured. Through the act of coming out, individuals were taking on, as was the case with one's ethnicity, a legitimate minority group identify that was in need of rights and protection like other minority groups (Nixon \& Givens, 2004).

\section{Being queer and an educator}

Despite the fact that there is a large push to diversify the teaching profession and evolve the school environment to become representative of the populations they serve, there is no active push to recruit queer identified teachers. Queer teachers were more successful the more they were able to meet heterosexual gender expectations (Jackson, 2006). This causes teachers to establish two different worlds for themselves; the private world which is their life outside of work where they can be queer, and their public world for work where they must be perform as heterosexual, or at the very least asexual (Gray, 2013). My own experiences as a queer educator 
are very similar to this, whereby I was not able to be open about myself or my sexuality while still being a professional. This dismissal of a queer identity is not only a passive part of the education system, but often also actively enforced by administrators, for example, when a teacher in a study by Neary (2013) approached a vice principal about creating an LGBTQI support group for students they were told, “Well we don't have a fat club, why would we have a gay club?” (p. 594).

Interactions with heterosexual colleagues

As noted in the literature, queer educators were often envious of the privilege their heterosexual colleagues held. One queer educator was quoted by Gray (2013) as stating, "Although I acknowledge that the sexuality of any teacher may not be deemed an appropriate topic for the classroom, it is relatively easy for heterosexual teachers to make references to 'my husband', 'my wife', or (opposite sex) partner and therefore make a statement about their sexuality" (p. 704). This can lead to queer teachers simply not share about themselves at all in a school environment, especially in the staff room, which is described as being, "difficult for LGB teachers because much of the conversation that occurs here is based upon heterosexual relationships" (Gray, 2013, p. 707). This point of the staff room was reiterated by Sean, a gay identified teacher in Neary's (2013) study, stating, "You don't bring private things up in the staff room" (p. 590). Sean stated that he regretted this reality of the staffroom because, "Your private life's your private life but that doesn't mean you should live in secret" (Neary, 2013, p, 590).

Queer teachers have also reported in the literature that they are actively censured by heterosexual colleagues. In Neary's (2013) study one lesbian teacher experienced this discrimination directly when, "One of the teachers in an adjoining school in the parish went to... 
the manager of my school and said a lesbian should not be teaching" (p. 588). In another study, a gay identified teacher named Kyle was confronted by a heterosexual teacher because she perceived his shirt to be too flamboyant. According to Chamness et al. (2010), the teacher told Kyle, "Don't ever wear that again. It's awful" (p. 1027). Kyle took this to mean, "It's too gay. I think she thought the shirt was too gay. That bothered me a little bit.” (p, 1027). In Ferfolja and Hopkins (2013) one of the gay male teachers reported that he was passed over for the opportunity to travel with students due to his being open with his sexuality. When he asked why he had been passed over for this opportunity he was told that the school had conducted a risk assessment, and as an unmarried openly gay man it was decided that he was too much of a safety risk to be permitted to travel with the students; it was also decided, however, a married heterosexual man and several unmarried heterosexual women were far less of a risk than an unmarried gay man to be traveling along with children (Ferfolja \& Hopkins, 2013). Acts such as this are supported by the notion previously discussed that queer teachers prey on children, and those queer teachers that are open about their sexual orientation are punished through official channels (King, 2004).

Occasionally, however, teachers reported that they would open themselves up to certain staff members. As one lesbian identified teacher, Anna, in Neary's (2013) study reported, “It's like an onion layer... with some teachers you might just be talking on the top layer and with others you might go a layer deeper" (p. 590). Queer teachers interviewed by Ferfolja and Hopkins (2013) were quoted as picking and choosing who exactly they would share information with and exactly how much information they would share. There is always the concern of safety, however, as one teacher described having to consider whether it is safe to share personal information about their lives, something heterosexual teachers were not perceived to need to 
consider, "There are times I am quite cautious in terms of, is that a safe arena I take myself into? And I think a straight person doesn't have to edit or censor their life in that way, and I do" (Ferfolja \& Hopkins, 2013, 321). There was reported backlash, however, as teachers in Neary's study, "Witnessed a reorganization of the hierarchical power entrenched in heterosexuality where colleagues were now conscious and careful not to 'offend' or afraid to 'put their foot in it' because of this new information." (Neary, 2013, p. 591). This reorganization showed itself through a perpetuation of new silences in the staffroom environment, where no dialog and singling out the queer teacher was deemed by the other teaching staff to be better than speaking with the queer teacher and potentially offending them.

Interactions with students

Some queer educators in the studies that were reviewed reported harassment and oppression by heterosexual students in their schools, and an inability to confront it (Gray, 2013; Ferfolja \& Hopkins, 2013; Lugg, 2006). For example, Kate, a 30 year old lesbian teacher from Gray's (2013) study reported being the victim of a homophobic campaign by students, "the kids'd yell, 'Lezza' at me. I had 'Miss __ is a lesbian' printed all over the toilets... Er you know they wrote all over the desks and all kinds of business" (p. 710). Kate was then barred by senior management from addressing the homophobic attacks she was experiencing in the school after coming out. She reported that she was the only openly queer member of the staff, and the administrators did not want her to engage the students as an open lesbian (Gray, 2013). Kevin, a gay identified teacher from Chamness et al.'s (2010) study, also reported being written about in the bathroom stalls, "When I first started at my school, my name was written in the girls and boys restroom stating, 'Mr. XXX is gay.' There have been several incidents where students have spread rumors about me being gay" (p. 1026). This is a similar experience to Alice from Ferfolja 
and Hopkins' (2013) study, who like Kate, was a lesbian teacher who was not permitted to reveal her sexuality to her students when she was the target of homophobic attacks. She was told that she could not address the issue by coming out to her students because, "We don't know where this is coming from because we don't have kids like that here" (p. 315).

Dealing with openly homosexual students in the educational setting was especially difficult for teachers who were not out themselves because of the teaching profession's, "Long history of homophobia," (Lugg, 2006, p. 46) and enforcement of gender roles. According to the literature, seeing queer and gender non-conforming students harassed and oppressed within the educational system caused concern for all queer teachers, however, most queer educators did not aid the students because of, "an unwillingness to be available to them for fear of discovery and ultimate job loss" (Mayo, 2008, p. 2). This makes interactions with openly or suspected queer students difficult as most teachers strictly avoided discussing anything relating to their sexuality in front of their students. As Michael, a gay teacher, described, "If I were really making overt references to me being gay in front of the kids, I think that may be where an issue would come up. Among other teachers, that's one thing, but if it started to influence my teaching, that would probably be a problem, I think" (p. 1026). Jackson (2006), however, reported that some teachers specifically come out to act as positive role models for queer students and to challenge the assumptions of heterosexual students, though no other article collected discussed this.

Fear of job loss

The fear of losing their jobs was a concern that was expressed by educators in all studies that were collected. It is in fact the major reason that teachers do not 'come out of the closet', for fear that they will be terminated, despite their feelings that they should be open an honest about 
who they really are (Gray, 2012). For those teachers who were not yet out at their schools, it was reported in Mayo's article that the belief that they would lose their job should they be open about their sexuality was a major anxiety (2008). The anxiety they feel is described by Jackson (2006) as, "The homophobia that threatens their jobs by spreading myths of molestation and recruitment, keeping their hands tied" (p. 32).

Being dismissed from their jobs is not the only fear experienced by queer educators. In Ferfolja and Hopkins (2013), several of the queer educators interviewed noted that they were just as afraid of, "Being overlooked for employment opportunities or promotion," (p. 317) as they were being dismissed for being perceived as queer. One of the queer teachers interviewed by Ferfolja and Hopskins (2013) said that when pulled into an administrator's office to discuss their homosexuality, they were told, "That if I talk about it, if I promote it then I will probably never get a job again... So I was there for two terms and I was hoping to extend... because there was a... position but both myself and my best friend who was also openly gay... they didn't hire any of us" (p. 317).

\section{Ontario Context}

Janmohamed, an instructor in the School of Early Childhood Studies at Ryerson, has written on queering early childhood education. Janmohamed (2013) did some of what this study aimed to do, which was to judge how queer issues are conveyed to pre-service early childhood educators in Ontario Colleges. She accomplished this through interviews, asking Early Childhood Education students at 4 Ontario colleges about issues they believed queer parents faced, and compared these interview results to what queer parents told her about their own experiences (Janmohamed, 2013). She found there was a disconnect between what the college 
students thought were key issues for queer parents compared to what queer parents actually felt. With these findings, Janmohamed and Ryan (2009) together created a resource for early childhood educators titled, "Building bridges: A resource and training guide for early childhood educators working with lesbian, gay, bisexual, transsexual and transgendered families". This guide, focused specifically on Ontario, offers resources, scenarios, as well as Janmohamed's own experiences as a lesbian mother, to teach early childhood professionals in the field how to work with queer populations.

\section{Common themes}

Throughout all three populations, children, parents, and educators, it is evident throughout the literature that the presumed heterosexuality in the early learning environment is harmful to all. It is not only harmful to the queer populations within the early learning environment, but to all other actors who are forced to follow and support heteronormative scripts. A strong pre-service curriculum for early childhood educators which combats the heteronormative assumptions of society and prepares early childhood educators to work with children in such a way that they are free to explore their own sexuality, to support queer parents and meet their specific needs, and to allow a space where queer educators, such as myself, are allowed to 'come out of the closet' at work and not need to separate professional from personal lives, is needed to give early childhood educators the tools, as well as the theoretical background to accomplish all of this. 


\section{Methodology}

Sample and recruitment

As the goal of this research is to analyze the curriculum of Ontario Colleges' Early Childhood Education programs, with a specific focus on how they train Early Childhood Educators (ECEs) to work with queer populations, the population being studied, and object of study is Ontario colleges' Early Childhood Education curriculum, as made available through course descriptions available online, course syllabi requested from the colleges, and from textbooks identified in course syllabi.

There are many colleges in Ontario, from small private colleges to larger publicly funded ones. I identified all colleges in Ontario and from this list, selected a sample for analysis. My first criterion for inclusion in this research was that colleges had to be publically funded. To create a list of these colleges I used a Google search, using the search terms "Publically funded Ontario Colleges". Using the results from this search, primarily a Wikipedia page with a list of Ontario Colleges, I was given a list of 24 Ontario colleges. I confirmed this number by comparing it with the number of colleges listed on ontariocolleges.com, the official online tool for potential students to apply to Ontario colleges. This webpage provided me with one more college to be considered, the Royal Military College in Kingston, which was not provided in the Wikipedia list.

With my list of 25 Ontario colleges, I began a process of selecting which programs I would contact. My process for selecting which colleges to contact was to check the college webpages and look for a program webpage for a program which would provide an Ontario College Diploma (OCD) in Early Childhood Education. As several Ontario colleges also offer 
degrees in Early Childhood Education, those programs were considered as well. The difference between the degrees in Early Childhood Education versus the diplomas are that the degrees are four years in length, rather than the 2 years for a diploma, and that the degrees are often designed to prepare the graduate for a leadership position within the field of early childhood education and care. After looking over the college webpages for ECE programs, 3 colleges were omitted from the final contact list: Royal Military College does not grant diplomas or degrees in Early Childhood Education, and both Collège Boréal in Sudbury and La Cité collégiale in Ottawa are French languages colleges. While I am able to fluently speak French, I feel my ability to write and read in French are not at a level needed for the analysis I would be required to do for this project. This gave me a final number of 22 colleges to contact (see Appendix A).

Between May $7^{\text {th }}$ and July $9^{\text {th }}$, I contacted the Ontario college programs via email. Whenever possible my emails were directed to the program coordinator and the administrative secretary. In some cases no contact information could be found for the program coordinator on either the program website or the college contact directory, so the generic contact email address for the program was used.

In my email I identified myself, my status as a student in the Master's in Early Childhood Studies program at Ryerson University, my goal to investigate how Ontario colleges train ECE students to work with queer populations, and invited the institutions to participate. After speaking with several professors at Ryerson University and recognizing just how sensitive these documents can be (and the fact that they are the intellectual property of individual professor and/or these institutions), I made sure to highlight that only I would be seeing these documents, and that no part of their syllabi would be published. Furthermore I felt it was important to specify that I was not looking to lay blame on specific colleges for a lack of material on working 
with queer families and their children, and specifically not to 'name and shame' them in my paper. The first contact email can be found in Appendix B. After the initial email, a follow up email was sent every two weeks to the various institutions to inquire on the status of my request. I wanted to make sure that those I was contacting would remember my request, especially during the summer months. A copy of the follow up email can be found in Appendix C.

Between May and July, a total of 11 of the 22 programs replied to my request for information by sending me their course materials, providing me with the course syllabi I requested and the names of the textbooks used in the courses.

Data collection

Data were collected from three separate sources in search for queer content. By the term 'queer content' what I mean is any content within any source which somehow relates to working with or educating students on working with queer parents, queer or gender non-conforming children, or queer educators. Pulos (2013) followed the same methodology in his analysis of queer content in online messages, looking specifically for queer content of both a 'positive' and 'negative' nature. Within my study I will be using the same term.

First and foremost I analyzed the websites of all 22 of the Ontario college ECE programs themselves. Each institution's ECE program had a website, and each institution also had their entire program description listed online. In all cases this means that the websites contained a semester by semester course breakdown of required courses, electives and diploma or degree requirements. Of the 22 program websites, 20 contained brief course descriptions. The first level of preliminary data collected was simply the listing of courses provided by the colleges' ECE program websites. This allowed me to request specific curriculum documents for specific 
courses, as well as see which institutions were offering which courses. All information was taken from the program websites during the month of May.

The second source of data came from the course syllabi from the 11 programs. This provided me with a total of 33 individual course syllabi. These provided valuable pieces of information, including: in-depth course descriptions and learning outcomes, a general indication of the amount of queer content and its location within the course as a whole, and the textbook used by the individual courses. These syllabi provided by the institutions were analyzed and considered at face value: it is assumed that the amount of queer content listed in the document more or less demonstrates how much is taught in the classroom, though I cannot be completely sure. I can only look at the curriculum which is formally written and presented. These documents are critically important in demonstrating what will be learned in a classroom, and what, ideally, students will take away from the course.

The final source of data for analysis were the 9 textbooks used by these programs in their foundation, family, anti-bias, and advocacy courses that I was able to retrieve from the Ryerson library. Despite the fact that these texts were not, in most cases, published or written specifically by instructors/professors at the selected institutions, they were critically important in the analysis of how Ontario ECEs were trained to work with queer populations. I assumed that the textbooks would provide fuller, richer text to deconstruct and analyze. While course documents are critical and provide a direct view of what the instructors and programs feel is important for students to learn, they often do not have the depth of content or images that a textbook contains. Furthermore, from my own experiences as a student, I have found that the content of a textbook is often what is adapted to the classroom, and readings from texts are critical to understanding the material that will be presented by the instructor. 


\section{Analytical Tools}

Two primary tools were used for the analysis of documents. The first was an excel spreadsheet used to document the course offerings by each Ontario college's ECE program. This spread sheet can be found in Appendix D. This spreadsheet provides a quick overview of what types of courses are offered by which Ontario college by putting them into categories, such as 'family focused course', 'ECE foundations focused course', 'social justice curriculum focused course', etc.

The second tool used for this paper was NVivo. NVivo is a tool used primarily in qualitative research. It is a computer program that can be used to input, sort and analyze various data, such as text, video, transcripts, photographs, etc. I was made familiar with the program while undertaking the Master's-level Social Research with Children course at Ryerson University during the winter of 2014. By using this program to code, nodes were created which can be used to quickly access and sort various data to see the formation of relationships and commonalities between them. All sections from textbooks relating to queer populations, as well as course syllabi were uploaded into NVivo for analysis and coding.

\section{Approach}

Analysis was done in three separate stages. The first stage was to assess queer content that is present in the brief, on-line course descriptions found on the program websites. The second stage was to analyse the course outlines that I received from the various college programs that responded to my request. Finally, I conducted a discourse analysis of the available textbooks listed in the various course outlines. The first two stages used content analysis to analyze the data for queer content (Krippendorff, 2004; White \& Marsh, 2006). Critical Discourse analysis was 
used for the analysis of textbooks (Fairclough, 2003). These two tools were used because as you recall, in this research I was attempting to answer two questions: firstly, do colleges train early childhood education students to work with queer populations, and secondly, how do they teach them to work with queer populations. A content analysis helped me to see if queer content was present in the online course descriptions and course documents. This helped to answer the first question, but is not sufficient to answer the second question. A critical look at the language and discourse used in the more complex items, the textbooks, was necessary to help answer the second question. Secondly, there was, in my opinion, not enough material in the course descriptions and course documents to conduct a proper discourse analysis, whereas there was more than enough text to analyse in the textbook offerings. For this reason, two separate analytical methods were used.

Like Pulos (2013), Schieble (2012), who analyzed text for queer content, and Lim (2014), who analyzed teacher curriculum, I decided to use Critical Discourse Analysis to analyze the textbooks identified in course documents for queer content. Like the three above mentioned authors, each of whom I will explain further in this section, I used Analyzing Discourse: textual analysis for social research by Fairclough (2003) as my primary text for conducting analysis.

Critical Discourse Analysis was first developed by linguists to look closely at language use rather than the strict literal meaning of what was being communicated through the written or oral text (Fairclough, 2003). What CDA allows, which simply analyzing the linguistics of communication does not, is the uncovering of the nature and connection between language, power, and ideology which is present in our texts (Fairclough, 2003). The connection between language and power have been written about by other theorists, such as Foucault (1975), who felt that power could not exist without language, as it was language which invariably created power. 
Using an approach such as critical discourse analysis provides a way to analyze the power and language which appears in the course documents.

The analysis of ideology is even more complex. Fairclough (2003) defines the inclusion of ideology as, "Representations of aspects of the world which can be shown to contribute to establishing, maintaining and changing social relations of power, domination and exploitation"' (p. 9). This means that CDA has been used in the past, as well as continues to be used, as a tool for political purposes and for social change.

With my review of the textbook content collected in this research, I relied heavily on two of concepts: difference and intertexuality. Difference, in terms of analysis, speaks to the social difference between various social identities. Fairclough (2003) states that the difference between various social identities (such as queer people, women, people of colour), in social research has become more pronounced. Examining social difference requires looking at the difference between the voice of the text and the social location of those being discussed. Fairclough (2003) writes that, "All texts are addressed, have particular addressees and readers in view, and assume and anticipate differences between 'author' and addressees" (p. 42). The social difference between the authors of the texts and those being discussed, queer families, will be analyzed.

The second concept used to analyze the text, interexuality, deals with what texts and voices are present in the text being analyzed. According to Fairclough (2003), this means answering such questions as, "Which texts and voices are included, which are excluded, and what significant absences are there?" (p. 47). These texts or voices can be incorporated either directly or indirectly, attributed or non-attributed, into the text being analyzed. For this research the intertexuality of the classroom text books will examined, to see which voices are present 
within the material being taught to early childhood education students, and which voices are absent.

In order to inform how I would analyze the texts for both the content analysis portion of the research as well as the critical discourse analysis part, I looked to several other authors who looked at either education or queer issues while using critical discourse analysis as their analytical tool. I found three authors who informed my method of analyzing the texts and whose methods or ideas were incorporated into my own writing.

The primary author that I used to influence my analysis of documents for queer content was Pulos (2013), who conducted a study on the heteronormativity in language used on message boards for the very popular massive multiplayer online (MMO) game, World of Warcraft. Pulos decided to conduct this investigation of the language used by players in this game after learning of an LGBTQ positive guild (a group of players who play together in the online world) which was threatened by the game's publisher, Blizzard Entertainment, for breaking rules pertaining to sexuality and sexual content in their game (Pulos, 2013). Pulos (2013) analyzed 500 messages posted online on World of Warcraft message board websites for how heteronormativity and homophobia impact the use of language by players of World of Warcraft. His findings showed that online digital spaces, particularly those in the gaming culture, were not welcoming to queer gamers.

Another article which used CDA in terms of education and pre-service teacher education was Schieble (2012) who examined pre-services teacher's beliefs, as posted on a course shell message board, on queer inclusion in classroom literature. Schieble (2012) used Fairclough's framework for the purposes of analysis, much as Pulos (2013) did, but took the analysis one step 
further. Schieble (2012) noted that much of the dialog in education surrounding queer inclusion in curriculum was highly superficial. Schieble's (2012) analysis of the posted comments also found that what was not being stated by the teachers was just as important as the words that were being used. Schieble (2012) found that what the teachers were not saying reinforced a highly conservative and heteronormative learning environment when discussing queer characters in material aimed at students and in non-heterosexual orientations in their classrooms. In my own analysis of the materials provided by the colleges, as well as in the textbooks, on top of looking at what was present and stated, I paid special attention to focus on what was not stated, and what content, sexualities, or identities were missing entirely.

In terms of using CDA to critically examine curriculum, I relied on Lim's (2014) analysis of critical thinking curriculum used by teachers in their classrooms. In his analysis Lim (2014) found that the curriculum, through use of language power, supported and impressed on students a neoliberal lens through which to view the world. Lim (2014), much as the previous authors discussed, also made use of Fairclaugh (2001), particularly the notion of repeated words and synonyms of such words to influence the world view of the student through repeated exposure to give the illusion of a fixed and stabled reality. This particular view of curriculum by Lim (2014) informed my analysis of Ontario college ECE curriculum by forcing me to consider a deeper meaning to the material presented and to look closer for an underlying ideology behind the view of queer inclusion in the early years.

In terms of content to be measured, there was a different criterion for what constituted queer content depending on the data analysed. For the website material and course outlines all that was measured/counted was the presence or use of the word 'queer', or LGBTQ, or any of the words stemming from the acronym. Simply being present was enough to be counted as queer 
content. For the textbooks more was required, and at least a dedicated paragraph on queer families, or any identity within the LGBTQ acronym was necessary to be included in the analysis. Once pieces of data were collected they were analyzed on three separate criteria: placement and context within the text, representation of the queer community as a whole and not simply specific subgroups within the community, and the language used to describe queer persons.

\section{Limitations/Delimitations}

There are several limitations to this study. First and foremost is participation. Despite several attempts to contact as many ECE programs at Ontario Colleges as possible, the response rate remained $50 \%$, with 11 out of the originally contacted 22 college's responding to my inquiry for information. There are several possible reasons for this, such as my contacting them during the summer when many are on holidays, a lack of time to forward the documents to me, concerns around intellectual property or fears of being scrutinized, etc. I feel that having just under half of the institutions respond, however, provides a good indication of how some College ECE programs train their students when it comes to working with queer populations.

Another limitation to this study is while I read and analyze curriculum documents, course offerings, and text book material; this does not necessarily provide a complete view of what is actually happening in the classroom. It is possible that individual instructors change the type and amount of queer content taught depending on their world views, personal preferences and experiences, or the way in which they themselves were taught. Some instructors may include more queer content in their classroom material, while others may include less. Being a graduate of an Ontario college ECE program I know that simply because material is included on a course 
syllabus does not necessarily mean that it will be covered in the classroom. I recall, during my time as a college student, several sections and chapters were ignored in the classroom so that we would have time to cover topics deemed by the instructor as being more important. This potential discrepancy between written policy documents and classroom practices was described by Wolfe (2006), who stated that we need a stronger connection between practice and policy in the training of Early Childhood Educators in order to correct the imbalance between queer parents and heterosexual parents by combating heteronormativity within the early learning field. For the purposes of this MRP, however, the assumption is being made that the policy and curriculum put in place by the Ontario College ECE programs more or less reflects what happens in the classroom.

One final limitation to this study was time. Due to the shortened focus of a major research paper over a master's thesis, the time frame for this study was approximately four months. This meant that time was a factor when collecting and analyzing data. If I had been able to have longer to complete this study I would have requested from the institutions to actually attend the classes when the queer content was being delivered in the classroom. The shortened timeframe and restriction to written documents and textbook material, however, provides an excellent starting location to see how pre-service Early Childhood Educators are trained in Ontario, and can help identify where to focus future studies or curriculum revision.

\section{Findings}

My findings when investigating the inclusion of queer content into Ontario college ECE curriculum will be presented in three parts. The first part will be information which is available to the public through the individual programs websites. This gives a very broad view of potential queer representation in Ontario college curriculum. The second part will be the 
analysis of the course syllabi that were collected from the 11 colleges who replied to my request for information. This provides a somewhat closer examination of queer representation in Ontario college curriculum by examining exactly what the individual programs have written in their own policy and curriculum. Third, the final section will deal with the analysis of the content found in textbooks used by the colleges. The majority of the analysis will take place in this section as classroom curriculum is often heavily influenced by the material found in the textbooks used for the course, and because there is simply more text to analyze.

\section{Website Information}

All information found in this following section was taken from the websites of the Ontario Colleges. All of the information used for analysis is easily accessible to the public, including potential students, and offers the first introduction of the specific Early Childhood Education program that the college offers. A chart documenting the full set of findings appears in Appendix D. All names of the colleges were changed to ensure privacy for the colleges in this study. All colleges were renamed and coded to include either LU (large urban), SU (small urban) or R (rural), followed by a number (for example: LU-3). Institutions were identified as either large urban, small urban, or rural using the same methodology that is used by Statistics Canada in identifying these regions: to be considered large urban the city where the program was located needed to have a population of at least 100,000 and a population density of 400 people per square kilometer. To be considered small urban it the city where the program was located needed to have a population of at least 1,000 and a population density of at least 400 people per square kilometer. If the location met only one or neither of these requirements, it was considered rural. On this chart the following information can be found: name given for the institution to ensure anonymity, language of instruction for the institution, whether the institution offers an 
Ontario College Diploma (OCD) in Early Childhood Education, and whether it offers an undergraduate degree in Early Childhood Education (or equivalent). The chart also documents whether the institution's ECE program contains a course dealing with the following material: a foundations/introduction to ECE course, a family focused course, an anti-bias/social justice course, a child abuse course, an inclusion-based course, and a sociology course. Courses based on this material were the courses of which syllabi were requested from the Ontario colleges. In the case of the family focused courses, the anti-bias/social justice courses, the inclusion based course, and the sociology based course, the brief course descriptions, as posted on the official program website, were examined for any queer representation.

In terms of language of instruction, 22 of the 24 Ontario colleges offers their diploma or degree program in English, while only 2 of the 24 offered them in French. No institution offered the Early Childhood Education program in French as well as in English. The French language institutions only offered diploma programs. While all 22 English-language programs at the Ontario colleges offered the diploma program, only 4 out of 22 offered a degree program as well. 3 out of the 4 institutions offered a Bachelor of Arts degree in Early Childhood Leadership along with a diploma in Early Childhood Education, with the remaining institution offering a Bachelor of Arts degree in Child Development. All four of the colleges offering degrees come from Large Urban Environments.

Analysis of Brief Course Descriptions of Families-centered Courses

Out of the 22 English-language colleges reviewed, 19 had at least one course focused specifically on working with families. Of those 19 colleges, 17 of them had descriptions posted on their websites describing their families course. Despite the fact that 13 of these course 
descriptions mention diversity in their course descriptions, no descriptions posted made any reference to same sex families or queer identified families. Different institutions defined diversity in different ways, such as LU-2 defining diversity it as, "Concepts of 'class', 'race', 'racism', and 'ethnic relations' are studied". Out of the 17 available course descriptions, concepts of 'race' or 'culture' are used by 8 of the colleges in their course descriptions. Rather than mention same sex or queer identified families, what is used in 7 of the outlines are language discussing 'forms' of families, 'diverse natures' of families, and 'contemporary family structures'. SU-4 specifically states that their families-centered course will address, "Ways to respond to the changing face of Canadian families". No program has any mention of queer families in their brief, on-line course descriptions.

Analysis of Brief Course Descriptions of Anti-bias/Social Justice-focused Courses

Out of the 22 colleges reviewed, 7 had at least one course focused specifically on developing an anti-bias or social justice focused curriculum. Of these 7 colleges, 5 of them are found in large urban environments. Of the original 7 colleges which offered a course specifically devoted to anti-bias or social justice focused curriculum, none of them mentioned in their course descriptions any queer content or queer people. 3 of the course descriptions offered vague explanations of offering an anti-bias framework, such as, "Students will explore their own values as they relate to anti-bias issues" stated in R-4's course description, and "this course will explore the nature of the anti-bias approach for children in the preschool setting" from SU-3. The other 3 course descriptions offered further information, however, on various identifiable types of families found in Ontario. One college from a rural environment focused specifically on Aboriginal families and children in their anti-bias curriculum, while R-5 stated that it would focus on, "cultural sensitivity, cultural competence and cultural safety". No queer content is 
specifically mentioned in course descriptions though vague statements of 'family diversity' and statements such as, "Traditional and current issues and practices that affect communities will be identified and examined," located on LU-13's webpage, could be interpreted as including same sex and queer identified families.

Analysis of Brief Course Descriptions of Advocacy/Community Action-focused Courses

Out of the 22 colleges reviewed, 14 of them included a course on advocacy. All but 4 of the course descriptions specify that the advocacy is specifically related to the childcare field. The course description for R-3's advocacy course specifically states that the course will teach Early Childhood Education students how to advocate, "For child care issues relating to children, family and child care programs." The course descriptions for the 4 programs which do not specifically mention the advocacy being focused on child care related issues used vague language to describe the goals of the courses. For example, the website for LU-1 stated that the course would provide students with the opportunity, "To take concrete action to support the wellbeing of children, families and our profession”. How this action will be taken,, or how this support will be offered is not specifically mentioned. No mention was found of queer people or queer content in any of these course descriptions.

\section{Analysis of Brief Course Descriptions of Inclusion Courses}

Out of the 22 ECE programs analyzed, 19 of them have at least one course focused primarily on inclusion. All but 2 of these course descriptions specifically state that the course is focused primarily on either children with disabilities, children with exceptionalities, or special education. The course description for LU-13 states that the course will in part examine, "Personal bias and wellness and their influence upon professional standards of practice". The 
specific course appears to be center more around creating a bias-free environment, but used the word 'inclusion'. It appears that courses using the term 'inclusion' focused only on children with disabilities, implying that within the field of early childhood education, the term 'inclusion' means only the inclusion of children with disabilities. None of the course descriptions from any of the programs made reference to queer peoples.

Analysis of Brief Course Descriptions of Sociology Courses

While the vast majority of the early childhood education programs included at least one course dealing with psychology, or in some cases specifically educational psychology, 4 of the programs included sociology courses rather than psychology courses. R-4 was the only college to include an English language description of its sociology course. In this specific program the goal is to provide students with, "The basic concepts of sociology related to socialization, social stratification, gender, class, race and culture". This description fits with many of the course descriptions in the anti-bias courses offered by the 7 programs which offer anti-bias courses. 2

of the 4 programs with sociology courses, R-2 and R-4, offer both a sociology course and an anti-bias course. None of the course descriptions for sociology courses contained any mention of queer people, sexuality, or sexual diversity.

\section{Analysis of Course Syllabi}

A total of 33 course syllabi from 11 different college ECE programs were analyzed for queer inclusion and any mention of same sex families, queer identified families, or working with gender independent or queer children. See Appendix E for a chart detailing the number of courses collected by program. Of the programs which submitted course outlines, 6 of them come from colleges in large urban environments, 3 of them come from colleges in small urban 
environments, and 2 come from colleges in rural communities. Course syllabi were sorted into one of four categories based on the content of the course: ECE foundations course, families course, anti-bias course, and advocacy course. Of each type of course sent to me by the ECE programs, 12 were foundation courses, 15 were families courses, 4 were anti-bias courses, and 2 were advocacy courses. Of these 33 syllabi that were analyzed only 5 made reference to any sort of queer content in the course or in the college/classroom code of conduct. In this case queer content was defined as any identification within the document specifically made to queer persons or same-sex families. Of the course syllabi with queer content, 4 came from programs based in large urban centers (LU-1, LU-4, and LU-6), while 1 came from a program based in a rural community (R-3). To further break down the places in which queer content was present in the course syllabi: 2 syllabi had queer content in the classroom conduct section, 1 syllabi had queer content in the learning outcomes, and 3 syllabi had queer content identified in weekly readings.

Classroom policy

All 33 of the course syllabi collected from the various college programs contained a section on classroom or institutional policy. While the classroom policies included rules and resources for students in the classroom, and all course syllabi collected included information for students with disabilities who required support in their studies, only two of the classroom policies specifically mention sexual orientation. Only Family 3, a diploma course, and Family 4, a degree course, both from LU-4, contained specific references to sexual orientation. The course syllabi for Family 4, for example, stated that students were to be respectful of all other students regardless of, "Race, class, gender, faith, age, ability, appearance, or sexual orientation". Other syllabi from other institutions were broader in their approach, such as the course syllabi for Family 1 at LU-1 which stated, "All incidents of harassment, discrimination, bullying, and 
violence will be addressed and responded to". Likewise SU-1 has on all of the course syllabi for this program, "Any form of misbehaviour, harassment or violence will not be tolerated." There is no specific mention for which type of harassment, against who, would not be tolerated.

\section{Learning outcomes}

All of the 33 course syllabi collected from the ECE programs contained learning outcomes. Only one course syllabi, Family 6 from LU-6 identified queer content specifically in the learning outcomes, stating that students will, "Describe the challenges unique to aboriginal families, multiracial families, grandparents raising grandchildren, teen families, foster families, adoptive and foster families, lesbian, gay, bisexual, transsexual, transgendered, separated, divorced, joint-custody, lone-parent, newcomer, and refugee families." There are themes present in the other course syllabi which do not specifically mention queer content. In 14 of the 33 course syllabi, 'diversity' is specifically mentioned in at least 1 learning outcome. For example, Family 2 from LU-3 states in the learning comes, "Demonstrate respect for diversity". Only one of the course syllabi, however, provides a definition for diversity. Family 4 from the LU-4 program states that diversity entails, "matters of 'class', 'race', 'racism', and 'ethnic relations"”. Queer or same-sex families are not included in this description of diversity. Furthermore, 6 of

the course outlines specifically state that students will develop respect for 'family diversity', but no definition is provided for what exactly family diversity entails.

Weekly course material / readings

Of the 33 course syllabi collected, only 3 were identified as having queer content in their weekly material or readings. To be considered to have queer content the course outline had to specifically state that the focus of the week or the reading was to discuss same-sex, queer, or 
LGBTQ families. The courses identified were Family 14 from the R-3 program, Family 4 from the LU-4 program, and Family 1 from the LU-1 program. The course material appeared in week 6 , week 7 , and week 9 , respectively. Family 4 specifically states the content of the course work that week and states that the content will be, "LGBTQ families and their children; supports for LGBTQ families". Family 14, likewise, identifies as the content for that week to be, "How best to support same-sex headed families and children". This analysis was a little more problematic and it is possible that more programs include weeks in which there is queer content in the course material and readings, but 17 of the 33 course syllabi that were given to me by the program directors did not in fact have any weekly breakdown of topics and readings. Instead, in most of the outlines, only overall themes and learning outcomes were given. The course syllabi without any weekly topics or readings listed in the course syllabi were marked with an N/A in Appendix

F. This means that if we look simply at the course syllabi with the weekly material and readings listed, 3 out of 16 available courses had this material available, meaning that approximately $18 \%$ of available course syllabi which included the weekly reading and material included queer content, rather than $9 \%$ when factoring in all 33 course syllabi.

\section{Textbook analysis}

From the 33 course outlines which were received, I was able to procure 9 of the textbooks identified as required reading from the Ryerson University library. Please see Appendix $\mathrm{G}$ for a detailed chart showing the textbooks, their authors, publication years, and which programs use them. The oldest text was printed in 1996 while the newest text was 2014, giving a range of 18 years between all of the textbooks. Of these textbooks 4 of them had queer content, while the other 5 had no substantial queer content. In order for a textbook to count as having 'substantial queer content', there had to be more than a paragraph devoted to queer 
families, children, or educators. Vague mentions of families with different values and 'lifestyles', as used in Crowther (2005), did not count as queer content.

Texts without queer content

Of the textbooks without any queer content whatsoever the text which stood out the most was Children at the Center by Blaxall, Kilbride, McKenna, Warberg, Yeates (1996), used by program SU-1 for course Foundation 7. To start, the publication of the book predates legal changes to the definition of families in Canada, so likely does not include queer content because of its age. But what stands out as interesting if the fact that a particular instructor or college program considers is still applicable and relevant, and not outdated, and so continues to be used in ECE teacher training. Given the book's age, being 18 years old, it makes no mention at all of sexual diversity in families. The very definition of what the text considers to be diversity in family lifestyle, reflects the time period in which it is written, as the text lists, "Single parents, one-and two-working-parent families, mothers and fathers in the home, extended families, interracial families, families with differently abled members, and families from different income levels" (Blaxall et. all, p. 224). Furthermore and not surprising given its age, when discussing an anti-bias curriculum, only issues of gender, age, ability, race, or culture are taken into consideration. In terms supporting different ('different' families meaning non-white, it would appear, due to this section being found in the larger section on anti-bias and anti-racist curriculum) families, the book relies on stereotypes of families and different backgrounds in its material. That said, they attempt to be inclusive because when discussing supporting parents, the authors state, "Our acceptance of and respect for families, regardless of different beliefs, backgrounds, or practices, is the foundation for a meaningful partnership" (Blaxall et. all, p. 378) (emphasis mine). 
Of the other 4 texts which I designated as not having any queer content, I could find no mention what so ever of queer parents or children in two of them, Introduction to early childhood education: a Canadian perspective by Crowther (2005), and Recent perspectives on early childhood education and care in Canada by Howe and Prochner (2012). And there was only a single line/sentence of text in two of them where they made mention of same-sex families: Essentials of early childhood education by Gestwicki and Bertrand (2008) and Foundations of early childhood education: Learning environments and childcare in Canada by Dietze (2006). I included the two previously named texts as having no content, despite the fact that they each had several lines spread throughout the texts, because without a dedicated section, or at least a paragraph, it does not allow me enough material to analyze.

The text by Dietze (2006) has only one line that I can find that makes reference to queer parents. In chapter 1, 'Exploring the foundations of early learning and childcare', family is discussed by the author. The changing state of the Canadian family is addressed as the text describes immigration patterns in Canada over what the text describes as the last 40 years (Dietze, 2006). Immigrant populations, as well as Aboriginal families, receive their own sections within this chapter. When discussing various compositions of the family unit found in Canadian society today, the text lists 9 examples, including teenage parents, grandparents raising children, and parents raising children that are not their own. The text lists these 9 different family compositions on page 24 . The $4^{\text {th }}$ family composition in this section is described as, "Single parent or two-parent families headed by gay or lesbian parents" (Dietze, 2006, p. 24). This description does not include any queer family structure that is not a one person or two person construct (such as raising a child communally), and it does not make any reference to any queer person other than gay men and lesbian women (such as transgender people or bisexuals). It is 
worthwhile to note that this text has the only section on family diversity in all textbook analyzed to include heterosexual two parent families, the family composition assumed to be the most common, in their lists on diversity, along with the other listed family units. This text does not put the heterosexual two parent families on top of the list (as some texts do, giving it a place of honour above all other family compositions) but rather includes this family composition as $5^{\text {th }}$ in the list.

Essentials of early childhood education, by Carol Gestwicki and Jane Bertrand (2008), is used as the primary textbook for Foundation Course 1 in the ECE program at LU-1. While this text does not contain any sections specific to queer parents or to same-sex families, it does contain one reference that I could find. The reference comes in Chapter 2 when discussing antibias curriculum in Canadian childcare programs. The text states, "Given the diversity of the Canadian population, it is more probable that your early child development program will include families with varying structures, including two parents of different genders, two of the same gender, single parents of either gender, and families headed by grandparents, adoptive parents, or foster parents". This list, which includes many different family types, is the only reference to queer parents that I could find in the text.

Texts with queer content

The text which stood out the most in terms of queer content as well as in utility, as three separate programs utilize the same text, was Partnerships: Families and communities in early childhood by Wilson (2014). The book is used by SU-1 for the Family 11 course, LU-4 for the Family 3 course, and LU-6 for the Family 6 course. Chapter 9, 'families we may meet', includes 11 pages dedicated to queer families. This section is by far the most comprehensive of all the 
texts with queer content. This section devoted to queer families provides information for the educator in the classroom, discusses the problems facing gay male educators, touches specifically upon gay fathers, and includes local Toronto resources such as the 519 Community Center, a centre that serves many queer groups, and provides services for queer youth and families in Toronto's diverse downtown Church and Wellesley Village (See http://www.the519.org for details).

While this chapter includes a good deal of information on queer families, there are some problems with the use of language throughout the chapter. The most apparent problem was the lack of any connection to either bisexual or transgender parents. While there is a section titled “Bisexual, Transsexual, Transgendered (which is erroneously written as 'transgendered' rather than 'transgender'), and Queer Families”, none of these identities, and their distinct needs and experiences are mentioned again, outside of a definition for the acronym LGBTQ. The second problem relating to language in this chapter is that the text assumes the reader is heterosexual. Within this text, when discussing societal laws and education, the words 'our' and 'we' are used. For example, on page 362, "Society tells gays and lesbians constantly through our laws, our acted our prejudices, and our ignorant and uncaring behaviour that they are unacceptable human beings" (Wilson, 2014) (emphasis my own). While the text is supportive of gays and lesbians, it is written in a manner that it is a privileged heterosexual writing about the experiences of oppressed queer people, for the education of other privileged heterosexuals. In other words, it 'others' gay and lesbian parents (more on this in the Discussion).

This chapter contains two images. The first is a pair of smiling white lesbians holding a child, on page 363 , with the caption, "Kim, Julie, and Charlie celebrating at their wedding" 
(Wilson, 2014). The second image used is the rainbow flag on page 370 with no caption, but with an explanation as to the meaning and history of the rainbow flag.

Furthermore, while Chapter 9 contains important information on queer families, unfortunately the same claim cannot be made for the rest of the book. The first chapter documents the 'changing face of the Canadian family', and discusses many topics from the 2008 economic downturn, the changing roles of women, the changing roles of men, the increase in divorce rates, changes in immigration, and many other ways in which Canadian society has progressed. The right of same-sex partners to marry in 2005 receives little attention, and only one sentence in the chapter touches on queer parents, "There is also increasing acceptance of same sex partners in Canada," (Wilson, 2014, p. 8). Queer parents receive no other acknowledgement in the text.

It is especially worth noting that in the course Family 6, at program LU-6, Chapter 9 of Wilson's (2014) book is the only chapter which is not listed in any of the assigned course readings, thus while the textbook is used in the course, the queer content in this book is not assigned to students taking the course.

Children: A chronological approach by Kail and Zolner (2009) is only used at LU-3 for the Foundations 2 course. This text includes 4 paragraphs on queer parents, identified in the text as 'gay and lesbian parents'. Bisexual and transgender parents receive no mention in any of the 4 paragraphs. This text is primarily concerned with comparing the children of gay and lesbian parents to heterosexual parents, and discussing the research surrounding this issue. The text makes statements such as, "In most respects, children of gay and lesbian parents resemble children of heterosexual parents," and, "there is no indication that people who are gay and 
lesbian are less effective in their parenting than people who are heterosexual" (Kail \& Zolner, 2009, p. 303). There are no pictures in the section on gay and lesbian parents. This text also includes a section on gay and lesbian adolescents under the title 'Sexual orientation' from pages 447 to 448 . This section contains a single photo of two white teenage females embracing on page 447. This image has the caption, "About 5 percent of teens identify themselves as gay" (Kail and Zolner, 2009, p. 447). This text includes no mention of bisexuality, transgender people, or any sexuality other than gay men and lesbian women.

Anti-bias education for young children and ourselves, by Louise Derman-Sparks and Julie Olsen Edwards (2010) is used only at SU-1 for the Anti-Bias 3 course. This text is written by American authors for a primarily American audience. Chapter 9 of this text, called 'Learning about family structures \& fairness', has a section devoted specifically to queer content. A section titled 'Supporting children in lesbian/gay-headed families', from pages 222 to 224, deals specifically with gay and lesbian families, including suggestions for inclusion and debunks popular myths about gay and lesbian families. Much of this chapter is devoted to strategies that can be used in the classroom to help children from gay and lesbian families combat homophobia that takes place in society. This text is highly focused on the, "Struggle for equality," (DermanSparks \& Olsen Edwards, 2010, p. 223) particularly in the civil rights gained by gay and lesbians in the United States in the last 30 years. There does not appear to be any queer content outside of this section, and there are no pictures present in this section. This text makes no references to bisexuality, transgender people, or any sexuality other than gay men and lesbians.

Choices and constraints in family life $2^{\text {nd }}$ edition by Maureen Baker (2010) is used by the LU-4 program for the course Family 4. This text contains a fair amount of queer content. For example, the index at the back of the book contains the following sections listed under gays and 
lesbians: ageing, cohabitation, marriage, household work, and parenting. Chapter 4 is included as part of the required readings in the course outline for Family 4, meaning the section on queer parenting identified in the index is included in the course readings. On page 113, under the heading 'New researching about childhood and parenting', is a small section on queer parenting. This section contains 2 paragraphs, and quickly discusses research related to gay and lesbian parents. This text is concerned primarily with providing research which states that children raised by gay and lesbian parents are in no way different from those raised in heterosexual families. It compares gay and lesbian parents to heterosexual parents constantly. For example the text states, "The children of same-sex couples studied are doing about as well as children normally do," (Baker, 2010, p. 113), a problematic statement stating that children growing up in heterosexual households are those who are growing 'normally'. This text is the sole text which includes a section on gay and lesbian parents creating their own 'fictive families', meaning families who are not biologically related but choose to come together and create family in order to offer support and raise children together (Baker, 2010). There are no pictures anywhere in this text. This text makes no references to bisexuality, transgender people, or any sexuality other than gay men and lesbians.

\section{Discussion}

Sexuality, particularly queer sexuality, has been treated in two separate ways within the broader educational atmosphere when analysing the curriculum documents for early childhood education curriculum within Ontario: the first is outright erasure, the second is to present queerness as an 'other' compared to the norm of heterosexuality. It could be argued that this is due to the effort within the classroom to deny sexuality to children (Robinson, 2008) by denying anything but heterosexuality (and even then only begrudgingly) in the early years classroom, 
Moving from informal to formal curriculum

The email by the program director that was quoted in the opening of this paper rings true for most of the course syllabi I received — while there may be informal covering of queer topics and issues during class (which I could not measure), there were very few formal references to queer individuals and families in almost all brief on-line course descriptions, course syllabi and course textbooks. Queer content may be covered within the classroom, informally, but I could not analyze and evaluate informal and undocumented curriculum. This begs the question then: why is this curriculum being taught (if it is being taught) in an informal manner? Why is this information not important enough to include in a formally written course syllabi or other instructional policy?

When I requested the course outlines that I requested from the ECE programs from all of the Ontario colleges, I was very specific in the courses I requested. I looked for courses that might have content on working with families, creating an anti-bias curriculum in the classroom, advocacy based courses, and foundational/introductory to ECE courses (which usually feature sections on Canadian families and Canadian society). Out of the 14 different family related course syllabi received, only 5 of them had mention of queer issues or queer families. No other courses, the 4 anti-bias courses, the 12 foundation courses, or the 2 advocacy courses, contained any queer content. The list of courses with queer content is even smaller when it is taken into consideration that 1 of those courses identified as having queer content, Family 3 at the LU-4 program, only has queer content in classroom policy rather than in the in class curriculum. If this course is removed from being considered as having queer content, for which the argument could be made, as the content in the course syllabi had nothing to do with the in-class curriculum itself that would mean that only 4 out of the 33 course syllabi had queer content. 
When looking at the 33 course syllabi collected for the purpose of this study, only 5 had any queer content, meaning that approximately $71 \%$ of the course syllabi collected from the ECE programs which identified course readings had no queer content whatsoever. When looking at the course syllabi of the 9 family based courses with no mention of queer content, I wonder if it is as the program director who emailed me stated, "We do discuss LGBTQ parents and the importance of creating an inclusive and open environment as the subject arises in curriculum, but this may not be represented in the curriculum documents you requested". Wolfe (2006), a college instructor who took it upon himself to include queer content into his classroom curriculum when none was offered, makes a point of saying that he chooses to include queer issues in his teaching of pre-service early childhood educators. Most programs appear to be designed for individual course instructors to make the choice to include the material, as Wolfe (2006) did, but true inclusion requires more than informal acceptance.

In their article on preschool curriculum and policy relating to the inclusion of queer families into early years programs, Fedewa and Candelaria (2013)_stated that oftentimes issues relating to queer content and queer inclusion are left to the personal choices of staff and directors. Fedewa and Candelaria (2013) stated that the inclusion of queer families into a program could be controversial, and for that reason alone there needed to be firm policy relating to inclusion and practices to make sure that these families were protected. For that reason I find the lack of any mention of queer content in $71 \%$ of the requested curriculum documents to be surprising. If Ontario ECE programs are indeed teaching this material but in an informal manner, it needs to be moved to and included in the formal curriculum. Just as Wolfe (2006) stated, as a vulnerable population that can be ignored, or worse, oppressed, due to personal opinions of those delivering service, so too can queer issues be ignored in the education of pre- 
service early childhood educators in Ontario if the individual instructors do not feel the need to teach the material. A formalized college curriculum, particularly for courses focused on working with families, protects both the course instructor who may want to teach the material as well as the families that the pre-service early childhood educators will one day be working with.

Janmohamed (2010) discussed Ontario curriculum in the study in which she interviewed instructors and students from 4 Ontario college ECE programs. She found the same issue I found through my study: a lack of queer content. Her work goes further than Wolfe's (2006), who simply states that queer content needs to be included, by actually providing a sample of what should be included. She offered several suggestions at the end of her study in the form of content which could be included into the college program curriculum, including course outlines for two theoretical courses dealing with queer inclusion and family diversity (Janmohamed, 2010). Clearly, four years later, my analysis shows that her suggestions have not be adopted. I did not find any college courses entirely devoted to queer inclusion in early childhood education, nor did I find much in terms of the inclusion of queer families in most courses which address family issues. . I see no reason why an entire course could not be included in the 4 Ontario college ECE programs that offer degrees. I believe there should be greater flexibility and wider course offerings given that they have a 4 year time frame to train students compared to the 2 years in Ontario College Diploma programs.

It is worth adding to this discussion that there are other programs outside of Ontario Colleges which provide training and education for Ontario Early Childhood Educators to work with queer families. Programs, such as the Building Bridges program created by Janmohamed and Campbell (2009), do exist in terms of professional development for Early Childhood Educators working in the field. These programs, however, only occur when dedicated staff 
members or directors arrange for this training to happen. This training is not mandatory for ECEs in Ontario. In order to maintain a workforce of ECEs in Ontario that is prepared and willing to work with queer families, this content needs to exist formally and comprehensively, in pre-service training.

Heteronormativity upheld through otherness

Heteronormativity, the belief that everyone is, or at least should be, heterosexual (Butler, 1990) is present in the course documents as well as the textbooks used in Ontario ECE programs. There are three ways this is done within the data I have collected: first, through the outright absence of queer content; second, through language used to describe queer families as 'others' and outside the norm; and finally, in the physical placement of queer content within the textbooks.

The most obvious way in which heteronormativity is upheld through the curriculum that was analyzed was through outright absence of queer content. When analyzing the intertexuality of these documents, to look to see what texts or voices are present within the text (Fairclough, 2003 ) it is very obvious to see that queer voices are missing. While the lack of queer voices is a concern even when there is text dealing with queer issues within the textbooks, the complete lack of acknowledgement of queer issues is pervasive and worthy of specific mention. Within the brief, on-line course descriptions there were no mentions at all of queer people, same-sex families, and LGBTQ parents. For example, despite the use of the terms 'culture' or 'race' by 8 out of the 17 course descriptions of family centered courses discussed in the findings section, no outline made any reference to queer content. When examining the course outlines, only 5 out of 33 had any queer content, and only 4 of those course outlines specifically mention any queer 
content in their curriculum. Only half of the textbooks examined had any identifiable queer content. Denying the experiences and needs of queer populations in the curriculum is the way in which heteronormativity is reinforced by the majority of the documents and texts analyzed. This is similar to the findings of Schieble (2012) in her study on queer characters in classroom literature. In this study Schieble (2012) described how heteronormativity learning environment was maintained by teachers refusing to acknowledge or speak about these characters and novels. In both her case, as well as in the documents analyzed in this paper, silence and absence maintains heteronormativity. When considering the theories of Foucault (1977, who argued that power was created through language and discourse, the removal of a group of people from the discourse effectively removes their own agency and power. Here, the importance and dominance of heterosexuality as the norm is supported and queer voices are silent and therefore made invisible (Butler, 1990)

The second way in which heteronormativity if supported through the course documents is by 'othering' the queer populations as represented within the textbooks. According to Kristin (2013) the goal of othering queer people is the same as colonizing: to make a specific group appear strange and outside of the dominant group. This occurs within a queer context by separating queerness from perceived heterosexuality and placing heterosexuality as the norm. The social difference (Fairclough, 2003) between the text, the voice of the author, and the subject of the text--the queer parents--is accentuated through the use of language. This is particularly evident when authors very literally insert themselves into the text to create the queer 'other'. This formation of the queer 'other' can be seen in this quote taken from the textbook written by Wilson (2014), "LGBTQ families engaged in their lifestyles at great personal risk and cost. Their commitment to parenting demands our respect" (p. 367). This statement at face value may 
seem supportive, until you ask who is the 'their' in the first sentence, and who is 'our' in the second sentence. These two sentences assume one thing: the reader is heterosexual. Despite the fact that Partnerships: Families and communities in early childhood is the text with the most information and the most useful tools for educators, including contact information for queer parenting programs and books for children to discuss family diversity (p. 371), the text itself constantly assumes a heterosexual voice. For example, the second sentence notes that queer families deserve more respect from educators than any other family compositions simply because they are headed by queer parents. But why is this the case, except in the fact that they mimic a heterosexual family composition? The two sentences could have been reworded to remove the assumption of heterosexuality if written like this: 'LGBTQ families form at great personal risk and cost. This commitment to parenting demands respect'. The social distance (Fairclough, 2003) between the author and subject is easily changed by removing the clearly heterosexual voice which creates the queer other. This othering of language is not, however, only found in the textbooks. Several of the classroom policies use the same language. For example, in the Family 3 course syllabi from program LU-4, the classroom policy states after the preamble that students should arrive on time and not use laptops, "Let's be careful to avoid remarks that may be offensive to others based on their race, class, gender, faith, age, ability, appearance, or sexual orientation". This statement is problematic, particularly the, '... may be offensive to others based on their race, gender...'. To students who are labeled as the 'others' in this statement, including queer students, students of colour, disabled students, this voice comes across as a heterosexual, white, able bodied voice. All of those listed are 'others', rather than students in the classroom. Furthermore the beginning of the statement, 'Let's be careful to avoid remarks that may be offensive...', does not take a firm stance on anti-bias language in the classroom. It reads 
closer to a polite suggestion rather than a statement barring offensive language from the classroom.

The final way in which heteronormativity is supported through these documents and texts is through the placement of the queer content. Research by Macgillivray and Jennings (2008), found that the placement of queer content in textbooks, where the material is placed in relation to other topics, and how it could reinforce negative stereotypes of queer people. I looked at placement and content in the same manner as Macgillivray and Jennings (2008), looking at how the placement of the content, not just the content itself, represented queer persons. By placement I mean where exactly within the document or text the queer content is found. For example, in the course syllabi for Family 1 received by institution LU-1, the first unit, "values success and stress in family life", has several topics which are covered. These topics, in order, are, "Divorce and separation; adoption; teen/lone parents; families and poverty; death and families; families with children with special needs; immigrant/refugees; same-sex families; First Nations families". The inclusion of same-sex families in this list that includes divorce, poverty, and death, not only creates a list of 'others' but of 'undesirables' as well. The message sent by this list is clear: these families are the others and problems which need our support because they are not 'normal'.

This is not limited to the course syllabi. In terms of the textbooks the queer content is usually framed and included with other 'others'. Partnerships: Families and communities in early childhood states in the chapter titled 'Families we may meet' that, "There is always a danger of organizing information in a way that leads to the assumption that families can be grouped together on the basis of similar characteristics and issues. In fact, nothing could be further from the truth!"' (Wilson, 2013, p. 324). This text does then, however, list several non- 
white, non-heterosexual, non-traditional family structures in this chapter. This means, when looking at the intertextuality of these textbooks, it is possible to see which voices are used and which are not (Fairclough, 2003). Within these texts, the white, heterosexual, two parent family is given voice, therefore normalizing it, while at the same time, othering all other types of family that are not included in the dominant discourse. The title as well, 'families we may meet', places a certain otherness to the families described. 'We' are not part of these families. In this chapter the following families are discussed: Aboriginal families; multi-racial families; older families; foster families; adoptive families; lesbian, gay, bisexual, transsexual, transgendered, and queer families; teen families; separated, divorced, joint-custody, and lone-parent families; widowed parents; blended families; migrant families; refugee families. This list, found in the second last chapter of the book, reads as a list of 'other' families that we 'may' meet. This means, of course, that the families we are most likely to meet are not these types of 'other' families. Here, along with so many 'other' families that we 'may' meet, queer families are presented as an other, separate and novel compared to the standard heterosexual family composition.

Children: A chronological approach by Kail and Zolner (2009) places their queer sections in a similar manner. In a chapter on teen sexuality, which, granted is outside the realm of early childhood, the section on LGBTQ teens is located between the section on sexual transmitted diseases (this section dealing specifically with HIV/Aids), and the section on date rape. Regardless of how the content in the section on LGBTQ teens may be written, it is sandwiched between two extremely sensitive and negative topics. The placement of the section sends the message that LGBTQ teens and their sexuality are just as dangerous to teenage life as sexually transmitted diseases and date rape. 
Becoming this 'other' disenfranchises queer families and robs them of their agency. Much as the disability rights activities saw themselves having this agency removed by a society dominated and designed for those who are able bodied (Marks, 1997), so too have queer families seen their agency and accessibility removed by a society dominated and designed for those who are heterosexual. This is a society which, even when filled with the best of intentions to represent queer families in a positive light, still represents queerness as the strange other, not a part of everyday life.

\section{Erasure of queer identities}

While the term LGBTQ (lesbian, gay, bisexual, transgender, queer) is often used as the acronym when speaking of the queer community, most often it is the $L$ and the $G$ which receives the attention. This erasure of the other components of the LGBTQ acronym, specifically the B (bisexual) and T (transgender) is evident in the course documents and textbooks. Despite the prevalence of the LGBTQ or GLBT acronyms in some texts and course syllabi, it is only the voices of gay men and lesbians which are given measure by the authors. When looking at these texts through the critical discourse lens, two issues seem to appear: first is the wide social difference between the bisexual and transgender subjects being discussed in the text. The second is that while the gay and lesbian voices are unattributed to actual gay and lesbian subjects (with the notable exception of Wilson, 2014, who includes gay and lesbian voices in boxes separate from the main text), bisexual and transgender voices are altogether absent (Fairclough, 2003).

The erasure of identities other than gay men and lesbian women has been documented by other researchers (Davidson, 2007; Erickson-Schroth \& Mitchell, 2009; Kaufmann, 2010; Yoshino, 2010). Erickson-Schroth and Mitchell (2009) document the history of identity erasure 
in both queer and heterosexual communities and argue that this erasure, especially within the queer community, comes from the ability of those who are bisexual or transgender to defy the homosexual-heterosexual dichotomy. Even within a queer community, the heteronormativity which states that there are two genders and rigid rules surrounding being attracted to only one gender can cause the erasure or mistrust of certain identities within the queer community (Yoshino, 2010).

The course outline for the course Family 6, from the LU-6 program, mentions learning to work with bisexual and 'transgendered' families in their learning outcomes for the course. The textbook used for this course, Partnerships: Families and communities in Canadian early childhood education, does not touch on the topics of bisexual or 'transgendered' families. I continue to use the term 'transgendered' in quotations marks as it is grammatically incorrect. To describe an individual who is transgender and has transitioned to another gender, the correct term is 'transitioned'. Transgender is as much an identity as being a man or woman, gay or lesbian. I would never refer to myself as having been 'manned' or 'gayed'. Both the course outline as well as the textbook also makes reference to transsexual parents. This term is controversial. Transsexual is a term primarily left over from when queer persons were seen as mentally ill and deviant. Though the term is occasionally used today, it is scarcely used within the queer community. The social distance between the authors of the texts and the subjects of these texts becomes obvious through the authors' incorrect use of terminology. The authors' misuse of terminology for these social identities contributes to robbing these social identities of power and agency (Fairclough, 2003).

Thus, transgender erasure is also common within the queer community. With the push to move forward the civil rights movement for queer persons, specifically the right to marriage and 
the right to adoption, many within the queer community have pushed away those who fall under the transgender umbrella in an effort to appear more 'normal' and palatable to heterosexual society (Davidson, 2007). This has caused the transgender community to turn more inward and become a community onto themselves. Within an ECE context, there are concerns and issues that transgender parents have that other queer parents would not have. For example, this past winter I conducted an interview with a transman (meaning the parent had transitioned from female to male) and his male partner. Together the two had a son which was biologically their own, as the transgender parent had stopped receiving testosterone injections in order to become pregnant. Once the two put their infant son into childcare they began to experience problems. Parents and staff at the childcare center had assumed that the couple was a same-sex couple until the transgender parent began to bring breast milk to the center for the son. The parents received backlash from the center as well as other parents. The transgender parent was also asked to leave a breast feeding discussion group hosted by the childcare program because it was for 'mothers only', and despite the fact that he was breast feeding his child, he was not allowed to attend.

The erasure of bisexuality has also been well documented. Yoshino (2010) discusses the erasure or bisexuality within the context of law and investments, but provides excellent background information on bisexuality. According to Yoshino (2010), part of the problem is the disconnect between sexuality, identity, and sexual behavior. A bisexual parent who is in a samesex marriage is not homosexual, regardless of whether they are with someone of the same sex. A bisexual parent who is in a heterosexual marriage is not heterosexual, regardless of whether they are with someone of a different sex. The identity of bisexuality is mixed with the behavior of being either in a homosexual or heterosexual relationship. This is particularly problematic for bisexuals as many, both inside and outside of the queer community, refuse to believe that 
bisexuality even exists (Yoshino, 2010). This belief is propagated by the idea that one cannot be attracted to both genders, but must choose one. Bisexuals are thus referred to as confused, unable to make up their minds, or simply sex-obsessed (Yoshino, 2010). Due to this widespread belief, their identity is often ignored and bisexuality is dismissed. How then could this identity be preserved and respected within an ECE classroom context?

Bisexual and transgender parents and families have their own concerns regarding identity and service, none of which are being represented in the curriculum which handles queer issues in the Ontario colleges. As previously stated in the findings section, all of the text books used which were analyzed spoke only on gay fathers and lesbian mothers. There is more to the queer community than gay men and lesbian women, and the curriculum taught to pre-service early childhood educators should reflect that.

Revisiting theoretical frameworks

The three frameworks--post structuralism, queer feminism, and critical disability theory — can help provide answers to the question of how power and domination are used to oppress queer population within the field of education. These theories help identify and explain the absence of representation, the erasure of identity, and the othering or queer populations. Discourse, according to Foucault (1975 is how power is created and made to influence the world. As discussed within this paper, the queer community is oftentimes completely absent from this discourse within the Ontario college ECE curriculum. With no voice within the discourse, there comes no power. When queer voices are included in the discussion, however, it appears to be in direct contrast to heterosexual parents and children, in a homosexual-heterosexual binary supported by heteronormative thinking (Butler, 1990). Queer families and the outcomes of 
children of queer parents, which many researchers have devoted time to (Berkowitz \& Ryan, 2011; Murphy, 2010; Rosenfeld 2010), are almost always compared to the children of heterosexual parents. Heteronormativity is at work through this thinking, assuming the heterosexual children from heterosexual families represent the norm to which queer families need to be compared. To tie in the last framework used, critical disability theory, this means that just as people with disabilities are disabled by the limits to access afforded them by our society rather than their impairment (Marks, 1997), we should similarly ask whose bodies, heterosexual or queer, are afforded limited access into our college classrooms and early learning environments.

\section{Limitations of study}

This study was limited primarily by program responses and time. While receiving information from 11 out of 22 programs gave a response rate of about 50\%, having access to more course outlines and more textbooks would have provided more data for what possibly could have been a deeper analysis. This is particularly a concern given that 6 out of the 11 programs which responded were from large urban environments, where the likelihood of encountering queer families may be higher. While 13 out of the 22 Ontario colleges are in large urban environments--just over half of all colleges--greater representation from small urban environments and rural environment would have allowed for a more complete picture of the current state of queerness in ECE program curriculum in Ontario.

Another limitation is the informal way it appears that queer issues are taught in Ontario ECE programs. Simply by analysing webpage material, course syllabi, and textbooks, I was not able to see what was actually being taught in the classroom or how it was being done. Had I 
more time and more scope with this research paper, I feel it would have been valuable to actually sit in on the specific classes where this material was being taught. This would give insight into the informal curriculum being taught in the ECE programs. Due to lack of time and access to the classrooms, only the content which was available in print in their course documents could be examined. It would be interesting in another study to compare the material from the course syllabi to what content was actually discussed and taught in the classroom setting.

\section{Conclusion}

The largest obstacle to queer concerns within the field of early childhood education and care appears to be, according to this project, the lack of formal curriculum recognizing queerness in the early years: be that queer families, educators, or children. The lack of a formal curriculum means that the queer community remains invisible in and to the early childhood education and care field and its educators. Most identifiable minority groups are represented and considered in curriculum, as shown by the focus of courses to include sections on race, culture, gender, and disability. The queer community, however, is not represented where many other communities are included.

Ontario Colleges' Early Childhood Education programs currently do not have a formal approach to the inclusion of queer people into their curriculum. For the most part I found that queer content was difficult to find in Ontario college Early Childhood Education documents, especially when compared to other issues of inclusion, such as race, gender, and culture. In the case of online course descriptions no content was found whatsoever. No perspective student, particularly a student who identifies with the queer community, could look at what individual early childhood education programs offer in terms of coursework, and find queer representation. 
Of the course syllabi that were collected, only 5 out of 33 contained any queer content, representing only $15 \%$ of all course syllabi requested contained any references to queer families. This is especially significant as only courses specifically dealing with introductions to the field of ECE, working with families, advocacy, and creating an anti-bias curriculum were requested-courses which should, ideally, have queer content. Of the 9 textbooks analyzed in this paper, only 4 contained at least 1 dedicated paragraph on queer parents or families. The content in those 4 texts, which was present and appeared to be written by the authors in a positive manner, was problematic. These texts which were analyzed succeeded in doing two things: othering queer parents and families by presenting them as strange alternatives to heterosexual families, and erasing all other queer identities other than gay men or lesbian women, such as bisexual men and women and transgender people, by completely ignoring them.

More than what was found, however, was what was not found. Of all of the places where queer content could have been, from online course descriptions to textbooks used in Ontario classrooms, heteronormativity, the widely held viewpoint that everyone is or should be heterosexual (Butler, 1990), was supported. The erasure of queer voices and experiences means that early childhood education students are being sent to work with families without any training on how to meet the needs of families who have every right to have access to childcare, be represented in their communities, and be respected as any two parent heterosexual family would. There are ways in which the heteronormativity of the classroom documents could be combated. The primary way the queer community can resist the problems or 'othering' and erasure within the Ontario college curriculum is for students to become involved in the early childhood education and care sector, and to push to change curriculum to become formally inclusive of queer identity, rather than settle for the informal representation of queer identity in the 
classroom. The queer community can make efforts to change the curriculum by either urging those in positions of power to change the curriculum, be those persons queer or heterosexual, or coming into those positions themselves to help push curriculum into becoming more formal and inclusive. This could be either within the Government of Ontario, or within the individual Early Childhood Education programs themselves. This will not be a quick change, and will require much effort and perseverance on the part of those looking to create change within the curriculum.

That said, several programs are making efforts to move towards more inclusive education by including some queer issues in their early years curriculum. As a province, though, we still have a long way to go before all Ontario trained ECEs can safely say they feel prepared to work with and support queer populations in the early years, be that a transgender parent, a 6 year old boy who speaks of his crush on members of the all boy band One Direction, or a fellow educator who simply wants to be able to bring her wife up in conversation without worrying that her career could be penalized for it. To combat the heteronormativity of the classroom we need to have formal policy put in place on the teaching of queerness in our college classrooms. It needs to be represented in our course outlines. Queer families need to be represented in our course textbooks, while at the same time acknowledging that some of the textbook readers are themselves part of queer communities. More than just representation, however, we need solid and honest representation of the specific challenges and needs faced by queer populations in a heterosexist environment, and know how to best support all families. If 6 out of 33 specifically selected course outlines mention in any way queer populations, or only half of the foundational and family related textbooks used by the colleges surveyed made any reference to queer populations, we can know that we have made inroads since 2005 , but we are still just building 
ramps. There is more work to be done for a truly inclusive education for those who will be working with the families of Ontario. 


\section{Appendix A}

List of college ECE programs contacted

\begin{tabular}{|l|l|}
\hline Algonquin College & Ottawa \\
\hline Cambrain College & Sudbury \\
\hline Canadore College & North Bay \\
\hline Centennial College & Toronto \\
\hline Conestoga College & Kitchener \\
\hline Confederation College & Thunder Bay \\
\hline Durham College & Oshawa \\
\hline Fanshawe College & London \\
\hline Fleming College & Peterborough \\
\hline George Brown College & Toronto \\
\hline Georgian College & Barrie \\
\hline Humber College & Toronto \\
\hline Lambton College & Sarnia \\
\hline Loyalist College & Belleville \\
\hline Mohawk College & Hamilton \\
\hline Niangara College & Welland \\
\hline Northern College & Timmins \\
\hline St. Claire College & Windsor \\
\hline St Lawrence College & Cornwall \\
\hline Sault College & Sault Ste. \\
\hline Seneca College & Marie \\
\hline Sheridan College & Toronto \\
\hline & Toronto \\
\hline & \\
\hline
\end{tabular}




\section{Appendix B}

Introduction email

Dear,

My name is Daniel Gosson, I am a graduate of Algonquin College's Early Childhood Education program, and I am currently completing my Master of Arts degree in Early Childhood Studies at Ryerson University. As part of my degree requirements I have chosen to conduct a major research paper (MRP) which I will be writing over the coming summer. I am contacting you because I would like to request certain documents from you in order to conduct my MRP.

The goal of my MRP is to examine how early childhood educators in Ontario college programs are trained to work with LGBTQ parents and families. To do this I am writing to request the syllabus and course outlines for the following courses:

My goal is to conduct a discourse analysis on the course documents as well as the textbooks identified in the course documents, to get a better understanding of how we prepare early childhood educators in Ontario to work with LGBTQ parents and families. I am emailing all Ontario Colleges with the same request.

Please rest assured that any and all documents that you share with me will only be seen by myself and my MRP supervisor, Dr. Patrizia Albanese, and no parts of any documents will be seen by or shared with anyone but my supervisor and myself. No parts of the documents will be published in the MRP itself or attributed to your institution. I am mindful of the sensitive nature of sharing course documents and will respect your institution's privacy and intellectual property by keeping all documents private and secure. Upon completion of the MRP I will delete any documents you have chosen to share with me.

I do hope that you will feel comfortable sharing these documents with me. The experiences of LGBTQ populations in Ontario childcare programs is not something that has been explored in great length. In the past, most childcare programs and directors took it upon themselves to provide in-service training and support for their educators to work with and support LGBTQ parents and families. Things have been changing/improving, and I'd like to help document that change. I feel strongly that if we are going to meet the needs of all families that are served by Ontario childcare programs, we need to fully assess just how we are preparing our graduates from early childhood education programs to work with them. I hope you agree.

If there is someone better suited to respond about the specific documents at your institution, could you please forward this email to them or provide me with their contact information?

I will be following up next week if I have not heard back from you. 


\section{Appendix C}

Follow up email

Dear,

Last week I contacted you, or your department, about sharing certain course files with me for my major research project (MRP). This MRP is part of my requirements for my Master of Art's degree in Ryerson Early Childhood Studies program. My paper is focused on conducting a discourse analysis of course syllabi for other documents to see how we train Ontario Early Childhood Education students who study at Ontario colleges to work with LGBTQ parents. I sent a similar request to all colleges in Ontario. As I have not heard from you I am sending an email to make sure that my request was received. I have included my original email under this email. I hope you take the time and consider my request. If you have any concerns please feel free to contact my supervisor, Dr. Patrizia Albanese, or myself. 


\section{Appendix D}

Program offerings spreadsheet

\begin{tabular}{|l|l|l|l|l|}
\hline Institution & $\begin{array}{l}\text { Language of } \\
\text { Instruction }\end{array}$ & $\begin{array}{l}\text { Offers } \\
\text { Diploma }\end{array}$ & Offers Degree & $\begin{array}{l}\text { Foundations/Introduction } \\
\text { to ECE course }\end{array}$ \\
\hline LU-1 & English & Yes & No & Yes \\
\hline LU-2 & English & Yes & Yes & Yes \\
\hline SU-1 & English & Yes & No & Yes \\
\hline R-1 & French & Yes & No & Yes \\
\hline SU-2 & English & Yes & No & Yes \\
\hline SU-3 & English & Yes & No & Yes \\
\hline LU-3 & English & Yes & No & Yes \\
\hline LU-4 & English & Yes & Yes & Yes \\
\hline LU-5 & English & Yes & Yes & Yes \\
\hline R-2 & English & Yes & No & No \\
\hline LU-6 & English & Yes & No & Yes \\
\hline R-3 & English & Yes & No & Yes \\
\hline SU-4 & English & Yes & No & Yes \\
\hline R-4 & English & Yes & No & Yes \\
\hline LU-7 & French & Yes & No & Yes \\
\hline SU-5 & English & Yes & No & Yes \\
\hline LU-8 & English & Yes & No & No \\
\hline LU-9 & English & Yes & No & Yes \\
\hline SU-6 & English & Yes & No & Yes \\
\hline LU-10 & English & Yes & No & Yes \\
\hline LU-11 & English & Yes & No & Yes \\
\hline LU-12 & English & Yes & Yes & Yes \\
\hline R-5 & English & Yes & No & No \\
\hline LU-13 & English & Yes & No & No \\
\hline
\end{tabular}


Program offering spreadsheet

\begin{tabular}{|c|c|c|c|c|}
\hline Family Course & $\begin{array}{l}\text { Queer content } \\
\text { in description? }\end{array}$ & $\begin{array}{l}\text { Anti-Bias/Social } \\
\text { Justice } \\
\text { Curriculum }\end{array}$ & $\begin{array}{l}\text { Queer content } \\
\text { in description? }\end{array}$ & $\begin{array}{l}\text { Community } \\
\text { Action/Advocacy } \\
\text { course }\end{array}$ \\
\hline Yes & No & No & - & Yes \\
\hline Yes & No & No & - & Yes \\
\hline Yes & No & Yes & No & No \\
\hline Yes & - & No & - & Yes \\
\hline No & - & No & - & No \\
\hline Yes & No & Yes & No & No \\
\hline Yes & No & No & - & No \\
\hline Yes & $\mathrm{N} / \mathrm{A}$ & No & $\mathrm{N} / \mathrm{A}$ & Yes \\
\hline Yes & No & No & - & $\begin{array}{l}\text { Yes (diploma } \\
\text { only) }\end{array}$ \\
\hline No & $\mathrm{N} / \mathrm{A}$ & Yes & $\mathrm{N} / \mathrm{A}$ & Yes \\
\hline Yes & No & Yes & No & Yes \\
\hline Yes & No & No & - & Yes \\
\hline No & - & No & - & No \\
\hline Yes & No & Yes & No & No \\
\hline Yes & - & No & - & yes \\
\hline Yes & No & No & - & No \\
\hline Yes & No & No & - & Yes \\
\hline Yes & No & No & - & No \\
\hline Yes & No & No & - & No \\
\hline Yes & $\mathrm{N} / \mathrm{A}$ & No & $\mathrm{N} / \mathrm{A}$ & Yes \\
\hline Yes & No & No & - & No \\
\hline Yes & No & $\begin{array}{l}\text { Yes (diploma } \\
\text { only) }\end{array}$ & No & Yes \\
\hline Yes & No & No & - & Yes \\
\hline Yes & No & Yes & No & Yes \\
\hline
\end{tabular}


Program offering spreadsheet

\begin{tabular}{|c|c|c|c|c|}
\hline Child Abuse & $\begin{array}{l}\text { Inclusion based } \\
\text { course }\end{array}$ & $\begin{array}{l}\text { Queer content } \\
\text { in description? }\end{array}$ & $\begin{array}{l}\text { Sociology } \\
\text { Course }\end{array}$ & $\begin{array}{l}\text { Queer content } \\
\text { in Description? }\end{array}$ \\
\hline Yes & Yes & No & No & - \\
\hline $\begin{array}{l}\text { Yes (diploma } \\
\text { only) }\end{array}$ & Yes & No & Yes & No \\
\hline No & Yes & No & No & - \\
\hline No & Yes & - & No & - \\
\hline No & Yes & No & No & - \\
\hline Yes & Yes & No & No & - \\
\hline No & Yes & No & No & - \\
\hline No & Yes & $\mathrm{N} / \mathrm{A}$ & Yes & $\mathrm{N} / \mathrm{A}$ \\
\hline $\begin{array}{l}\text { Yes (diploma } \\
\text { only) }\end{array}$ & Yes & No & No & - \\
\hline Yes & No & $\mathrm{N} / \mathrm{A}$ & Yes & $\mathrm{N} / \mathrm{A}$ \\
\hline No & Yes & No & No & - \\
\hline No & No & - & No & - \\
\hline No & No & - & No & - \\
\hline No & Yes & No & Yes & No \\
\hline No & Yes & - & No & - \\
\hline No & Yes & No & No & - \\
\hline No & Yes & - & No & - \\
\hline Yes & Yes & No & No & - \\
\hline No & No & - & No & - \\
\hline No & No & - & No & - \\
\hline No & Yes & No & No & - \\
\hline No & Yes & No & No & - \\
\hline No & Yes & No & No & - \\
\hline No & Yes & No & No & - \\
\hline
\end{tabular}




\section{Appendix E}

Number of syllabi received per program

\begin{tabular}{|c|c|c|}
\hline Institution & $\begin{array}{l}\text { Course sylibi received } \\
\text { from Institution }\end{array}$ & $\begin{array}{l}\text { Course sylibi directly } \\
\text { referencing queer content }\end{array}$ \\
\hline LU-1 & 2 & 1 \\
\hline LU-3 & 2 & 0 \\
\hline LU-4 & 4 & 2 \\
\hline LU-6 & 4 & 1 \\
\hline LU-8 & 4 & 0 \\
\hline LU-10 & 3 & 0 \\
\hline SU-1 & 3 & 0 \\
\hline SU-4 & 3 & 0 \\
\hline SU-5 & 2 & 0 \\
\hline$R-3$ & 3 & 1 \\
\hline \multirow[t]{2}{*}{$R-4$} & 3 & 0 \\
\hline & Total: 33 & Total: 5 \\
\hline
\end{tabular}




\section{Appendix F}

Course syllabi by program and topic

\begin{tabular}{|c|c|c|c|c|c|c|c|}
\hline Institution & Course & $\begin{array}{l}\text { Diploma or } \\
\text { Degree }\end{array}$ & $\begin{array}{l}\text { Queerness } \\
\text { present in } \\
\text { document }\end{array}$ & $\begin{array}{l}\text { Queerness in } \\
\text { classroom } \\
\text { policy }\end{array}$ & $\begin{array}{l}\text { Queerness in } \\
\text { learning } \\
\text { outcomes }\end{array}$ & $\begin{array}{l}\text { Queerness } \\
\text { identified in } \\
\text { readings }\end{array}$ & $\begin{array}{l}\text { Week Queer } \\
\text { Content } \\
\text { Appears }\end{array}$ \\
\hline \multirow[t]{2}{*}{ LU-1 } & Foundation 1 & Diploma & No & No & No & No & None \\
\hline & Family 1 & Diploma & Yes & No & No & Yes & Week 6 or 7 \\
\hline \multirow[t]{2}{*}{ LU-3 } & Foundation 2 & Diploma & No & No & No & No & None \\
\hline & Family 2 & Diploma & No & No & No & No & None \\
\hline \multirow[t]{4}{*}{ LU-4 } & Foundation 3 & Diploma & No & No & No & No & None \\
\hline & Family 3 & Diploma & Yes & Yes & No & No & None \\
\hline & Family 4 & Degree & Yes & Yes & No & Yes & Week 7 \\
\hline & Anti-Bias 1 & Degree & No & No & No & No & None \\
\hline \multirow[t]{4}{*}{ LU-6 } & Foundation 4 & Diploma & No & No & No & No & N/A \\
\hline & Family 5 & Diploma & No & No & No & No & N/A \\
\hline & Family 6 & Diploma & Yes & No & Yes & No & N/A \\
\hline & Anti-Bias 2 & Diploma & No & No & No & No & N/A \\
\hline \multirow[t]{4}{*}{ LU-8 } & Foundation 5 & Diploma & No & No & No & No & N/A \\
\hline & Family 7 & Diploma & No & No & No & No & N/A \\
\hline & Family 8 & Diploma & No & No & No & No & N/A \\
\hline & Family 9 & Diploma & No & No & No & No & N/A \\
\hline \multirow[t]{3}{*}{ LU-10 } & Foundation 6 & Diploma & No & No & No & No & N/A \\
\hline & Family 10 & Diploma & No & No & No & No & N/A \\
\hline & Advocacy 1 & Diploma & No & No & No & No & N/A \\
\hline \multirow[t]{3}{*}{ SU-1 } & Foundation 7 & Diploma & No & No & No & No & N/A \\
\hline & Family 11 & Diploma & No & No & No & No & N/A \\
\hline & Anti-Bias 3 & Diploma & No & No & No & No & N/A \\
\hline \multirow[t]{3}{*}{ SU-4 } & Foundation 8 & Diploma & No & No & No & No & None \\
\hline & Foundation 9 & Diploma & No & No & No & No & None \\
\hline & Family 12 & Diploma & No & No & No & No & None \\
\hline \multirow[t]{2}{*}{ SU-5 } & Foundation 10 & Diploma & No & No & No & No & None \\
\hline & Family 13 & Diploma & No & No & No & No & None \\
\hline \multirow[t]{3}{*}{ R-3 } & Foundation 11 & Diploma & No & No & No & No & None \\
\hline & Family 14 & Diploma & Yes & No & No & Yes & Week 9 \\
\hline & Advocacy 2 & Diploma & No & No & No & No & None \\
\hline \multirow[t]{3}{*}{$\mathrm{R}-4$} & Foundation 12 & Diploma & No & No & No & No & N/A \\
\hline & Family 15 & Diploma & No & No & No & No & N/A \\
\hline & Anti-Bias 4 & Diploma & No & No & No & No & N/A \\
\hline
\end{tabular}




\section{Appendix G}

Textbook analysis

\begin{tabular}{|c|c|c|c|c|c|}
\hline Text Title & Text Author & Year of Printing & $\begin{array}{l}\text { Is the textbook } \\
\text { Canadian? }\end{array}$ & $\begin{array}{l}\text { Program }+ \\
\text { Course where } \\
\text { text is used }\end{array}$ & $\begin{array}{l}\text { Significant queer } \\
\text { content? }\end{array}$ \\
\hline $\begin{array}{l}\text { Anti-bias } \\
\text { education for } \\
\text { young children } \\
\text { and ourselves }\end{array}$ & $\begin{array}{l}\text { Derman-Sparks, } \\
\text { L., \& Olsen } \\
\text { Edwards, J. }\end{array}$ & 2010 & No & $\begin{array}{l}\text { SU-1 (Anti-bias } \\
3 \text { ) }\end{array}$ & Yes \\
\hline $\begin{array}{l}\text { Children a } \\
\text { chronological } \\
\text { approach 2nd } \\
\text { edition }\end{array}$ & $\begin{array}{l}\text { Kail, R., \& } \\
\text { Zolner, T. }\end{array}$ & 2009 & Yes & $\begin{array}{l}\text { LU-3 } \\
\text { (Foundation 2) }\end{array}$ & Yes \\
\hline $\begin{array}{l}\text { Children at the } \\
\text { centre: } \\
\text { Principles of } \\
\text { early childhood } \\
\text { education in } \\
\text { Canada 1st } \\
\text { edition }\end{array}$ & $\begin{array}{l}\text { Blaxall, J., } \\
\text { Kilbride, K. M., } \\
\text { McKenna, D., } \\
\text { Warberg, C., } \\
\text { Yeates, M. }\end{array}$ & 1996 & Yes & $\begin{array}{l}\text { SU-1 } \\
\text { (Foundation 7) }\end{array}$ & No \\
\hline $\begin{array}{l}\text { Choices and } \\
\text { constraints in } \\
\text { family life 2nd } \\
\text { edition }\end{array}$ & Baker, M. & 2010 & Yes & LU-4 (Family 4) & Yes \\
\hline $\begin{array}{l}\text { Essentials of } \\
\text { early childhood } \\
\text { education }\end{array}$ & $\begin{array}{l}\text { Gestwicki, C., } \\
\text { Bertrand, J. }\end{array}$ & 2008 & Yes & $\begin{array}{l}\text { LU-1 } \\
\text { (Foundation 1) }\end{array}$ & No* \\
\hline $\begin{array}{l}\text { Foundations of } \\
\text { early childhood } \\
\text { education: } \\
\text { Learning } \\
\text { environments } \\
\text { and childcare in } \\
\text { Canada }\end{array}$ & Dietze, B. & 2006 & Yes & $\begin{array}{l}\text { SU-5 } \\
\text { (Foundation 7) }\end{array}$ & No* \\
\hline $\begin{array}{l}\text { Introduction to } \\
\text { early childhood } \\
\text { education: a } \\
\text { Canadian } \\
\text { perspective }\end{array}$ & Crowther, I. & 2005 & Yes & $\begin{array}{l}\text { LU-6 } \\
\text { (Foundation 4) }\end{array}$ & No \\
\hline $\begin{array}{l}\text { Partnerships: } \\
\text { Families and } \\
\text { communities in } \\
\text { early childhood }\end{array}$ & Wilson, L. & 2014 & Yes & $\begin{array}{l}\text { SU-1 (Family } \\
\text { 11), LU-4 } \\
\text { (Family 3), LU- } \\
6 \text { (Family 6) }\end{array}$ & Yes \\
\hline $\begin{array}{l}\text { Recent } \\
\text { perspectives on } \\
\text { early childhood } \\
\text { education and } \\
\text { care in Canada }\end{array}$ & $\begin{array}{l}\text { Howe, N., \& } \\
\text { Prochner, L. }\end{array}$ & 2012 & Yes & $\begin{array}{l}\text { LU-4 (Anti-bias } \\
\text { 1) }\end{array}$ & No \\
\hline
\end{tabular}

No* signifies that there was some content, but it was deemed not to be a significant amount (less than a paragraph) 


\section{References}

Baker, M. 2010. Choices and constraints in family life ( $2^{\text {nd }}$ ed.). Don Mills: Oxford University Press.

Becker, A., \& Todd, M. 2013. A new American family? Public opinion toward family status and perceptions of the challenges faced by children of same sex parents. Journal of GLBT family studies, 9, pp. 425 - 448. DOI: 10.1080/1550428X.2013.822841

Berkowitz, D., Ryan., M. 2011. Bathrooms, baseball, and bra shopping: Lesbian and gay parents talk about engendering their children. Sociological perspectives, 54 (3), pp. 329 - 350. DOI: $10.1525 /$ sop.2011.54.3.329

Blaxall, Kilbride, McKenna, Warberg, Yeates. 1996. Children at the centre: Principals of early childhood education in Canada. Toronto: Harcourt Brace.

Butler, J. (1990) "Performative Acts and Gender Constitution: An Essay in Phenomenology and Feminist Theory." Performing Feminisms: Feminist Critical Theory and Theatre. Ed. Sue-Ellen Case. Baltimore: Johns Hopkins UP

Butler, J. (2004). Undoing gender. New York: Routledge. Chicago

Chamness P., Reece-Miller P., Santavicca N. (2010). Surviving in the trenches: A narrative inquiry into queer teachers' experiences and identity. Teaching and teacher education, 26, pp. $1023-1030$.

Crowther, I. 2005. Introduction to early childhood education: A Canadian perspective. Toronto: Thomson Canada. 
Davidson, M. (2007). Seeking refuge under the umbrella: Inclusion, exclusion, and organizing within the category transgender. Sexuality Research \& Social Policy, 4(4), 60-80

Derman-Sparks, L., \& Edwards, J. 2010. Anti-bias education for young children and ourselves. Washington: National association for the education of young children.

Dietze, B. 2006. Foundations of early childhood education: learning environments and childcare in Canada. Toronto: Pearson Education Canada.

Erickson-Schroth, L., \& Mitchell, J. (2009). Queering queer theory, or why bisexuality matters. Journal of Bisexuality, 9(3-4), 297-315.

Fairclough, N. 2003 Analysing discourse: Textual analysis for social research. New York: Routledge

Fedewa, L. \& Candelaria, A. (2013) Creating safe and supportive learning Environments: A Guide for Working with Lesbian, Gay, Bisexual, Transgender, And Questioning Youth and Families. New York : Routledge Taylor \& Francis Group.

Ferfolija, T., Hopkina, L. (2013). The complexities of workplace experience for lesbian and gay teachers. Critical studies in education, 52(3), pp. 311 - 324Foucault 1980

Foucault, M (1980), Body/Power and Truth Power. Michel Foucault: Power/Knowledge, U.K.: Harvester.

Foucault, M. (1978). The History of Sexuality, translated by R. Hurley, Penguin Books. Foucault, M. (1977). Discipline and Punish: The Birth of the Prison, trans. A. Sheridan, Garcia, A. M., \& Slesaransky-Poe, G. (2010). The heteronormative classroom: 
Questioning and liberating practices. Teacher Educator, 45(4), 244-256.

Gestwicki, C., \& Bertrand, J. 2008. Essentials of early childhood education ( ${ }^{\text {rd }}$ ed.). Toronto: Thomson Canada.

Gray, E. (2013). Coming out as a lesbian, gay or bisexual teacher: negotiating private and professional worlds. Sex education, 13(6), pp. $702-714$.

Gunn, A. (2011). Even if you say it three ways, it still doesn't make it true: The pervasiveness of heteronormativity in early childhood education. Journal of Early Childhood Research, 9(3), 280-290

Gunn, A. C., \& Surtees, N. (2010). (Re)marking heteronormativity: resisting practices in early childhood education contexts. Australasian Journal of Early Childhood, 35(1), 42.

Howe, N., \& Prochner, L. 2012. Recent perspectives on early childhood education and care in Canada. Toronto: University of Toronto press.

Janmohamed, Z. (2013). When queer enters early childhood teacher training: What's so inappropriate about that? in V. Pacini-Ketchabaw \& L. Prochner (Eds.), Re-situating Canadian early childhood education (pp. 90 - 105). New York, NY: Peter Lang.

Janmohamed, Z. (2010). Queering early childhood studies: Challenging the discourse of developmentally appropriate practice. Alberta Journal of Educational Research, 56(3), 304-318.

Janmohamed, Z. (2009). Building bridges : Queer families in early childhood education. The Atkinson center for society and child development. 
Jackson, J. (2006). Removing the masks: Considerations by gay and lesbian teachers when negotiating the closet door. Journal of poverty, 10(2), pp. $27-52$.

Kail, R., \& Zolner, T. 2009. Children: A chronological approach (2 ${ }^{\text {nd }}$ ed.). Toronto: Pearson education Canada.

Kaufmann, J. (2010). Trans-representation. Qualitative Inquiry, 16(2), 104-115

King, J. (2004). The (im)possibility of gay teachers for young children. Theory into practice, 43(2), pp. $122-127$.

Knopf, T. 2013. Portrait of a transgender marriage. The gay and lesbian review worldwide, 20 (4), pp. $15-20$.

Krippendorff, K. (2004). Content analysis: an introduction to its methodology. Thousand Oaks, California: Sage

Smith, K. (2013). Decolonizing queer pedagogy. Affilia, 28(4), 468-470

Lev, A. 2010. How queer! - The development of Gender identity and sexual orientation in LGBTQ-headed families. Family process, 49 (3), pp. 268 - 290.

Lim, L. (2014). Ideology, rationality and reproduction in education: A critical discourse analysis. Discourse: Studies in the Cultural Politics of Education, 35(1), 61-76. doi:10.1080/01596306.2012.739467

Lugg, C. (2006). Thinking about sodomy: Public schools, legal panopticons, and queers. Educational policy, 20(1), pp. 35 - 58. 
Macgillivray, I. K. \& Jennings, T. (2008). A content analysis exploring lesbian, gay, bisexual, and transgender topics in foundations of education textbooks. Journal of Teacher Education, 59(2), 170-188.

Marks, D. (1997). Models of disability. Disability and rehabilitation, 19(3), pp. $85-91$.

Mayo, J.B. (2008). Gay teachers' negotiated interactions with their students and (straight) c olleagues. The high school journal, 92(1), pp. $1-10$.

Moore, M., Stambolis-Ruhstorfer, M. 2013. LGBT sexuality and families at the start of the twenty-first century. The annual review of scociology, pp. 491 - 507. DOI: 10.1146/annurev-soc-071312-145643

Mulé, N. J., \& Smith, M. (2014). Invisible populations: LGBTQ people and federal health policy in Canada. Canadian Public Administration, 57(2), 234-255.

Murphy, T. 2010. The ethics of helping transgender men and women have children. Perspectives in biology and medicine, 53 (1), pp. 46-60. DOI: 10.1353/pbm.0.0138

Myers, K., \& Raymond, L. (2010). Elementary school girls and heteronormativity: The girl project. Gender \& Society, 24(2), 167-188.

Neary, A. (2013). Lesbian and gay teachers' experiences of 'coming out' in Irish schools. British journal of sociology of education, 34(4), 583-206.

Nixon, D., Givens, N. (2004). 'Miss, you're so gay.' Queer stories from trainee teachers. Sex Education, 4(3), pp. $217-237$ 
Peters, W. (2005). Queer identities: Rupturing identity categories and negotiating meanings of queer. Canadian Woman Studies, 24(2), 102-107

Pulos, A. (2013). Confronting heteronormativity in online games: A critical discourse analysis of LGBTQ sexuality in world of warcraft. Games and Culture, 8(2), 77-97

Robinson, K. H. (2013). Building respectful relationships early: Educating children on gender variance and sexual diversity. A response to Damien Riggs. Contemporary Issues in Early Childhood, 14(1), 81-87

Robinson, K. (2012). 'Difficult citizenship': The precarious relationships between childhood, sexuality and access to knowledge. Sexualities, 15(3/4), 257-276

Robinson, K. (2008). In the name of 'childhood innocence': A discursive exploration of the moral panic associated with childhood and sexuality. Cultural Studies Review, 14(2), 113-129.

Robinson, K., \& Davies, C. (2008). Docile bodies and heteronormative moral subjects: Constructing the child and sexual knowledge in schooling. Sexuality \& Culture, 12, 221239

Rosenfield, M. 2010. Nontraditional families and childhood progress through school. Demography, 47 (3), p. 755 - 775. Retrieved from http://www.jstor.org/stable/40800840

Ryerson Discrimination and Harassment Prevention Services. 2014. Positive space mission. Retrieved from http://www.ryerson.ca/equity/positivespace/mission.html 
Schieble, M. (2012). A critical discourse analysis of teachers' views on LGBT literature. Discourse: Studies in the Cultural Politics of Education, 33(2), 207-222.

Statistics Canada. 2011. Portrait of families and living arrangements in Canada: Families, households and marital status, 2011 census of population. (Catalogue no. 98-312X2011001). Retrieved from http://www12.statcan.gc.ca/census-recensement/2011/assa/98-312-x/98-312-x2011001-eng.pdf

Surtees, N., \& Gunn, A. C. (2010). (Re)marking heteronormativity: Resisting practices in early childhood education contexts. Australasian Journal of Early Childhood, 35(1), 42-47

The union for the physically impaired against segregation. (1975) Comments on the discussion held between the Union and the Disability Alliance on 22nd November, 1975. Fundamental principals of disability, pp. 1-9. Retrieved from http://disabilitystudies.leeds.ac.uk/files/library/finkelstein-UPIAS-Principles-2.pdf.

Vanier Institute of the Family. 2013. Fascinating families. Retrieved from http://www.vanierinstitute.ca/include/get.php?nodeid=2817

White, M., \& Marsh, E. 2006. Content analysis: A flexible methodology. Library trends, 55(1), pp. $22-45$.

Wilson, L. 2014. Partnerships: Families and communities in early childhood $\left(5^{\text {th }}\right.$ ed.). Toronto: Nelson education.

Wolfe, R. 2006. Choosing to include gay issues in early childhood teacher preparation coursework: One professor's journey. Journal of early childhood education, 27, pp. 194 - 204. DOI: $10.1080 / 10901020600675174$ 
Yoshino, K. 2010. The Epistemic Contract of Bisexual Erasure. Stanford law review, 52(2), pp. 353-461. 